\title{
Bank Valuation and Its Connections with the Subprime Mortgage Crisis and Basel II Capital Accord
}

\author{
C. H. Fouche, ${ }^{1}$ J. Mukuddem-Petersen ${ }^{2}$ M. A. Petersen,${ }^{2}$ and M. C. Senosi ${ }^{2}$ \\ ${ }^{1}$ Absa Bank, Division of Retail Banking Business Performance, 2000 Johannesburg, South Africa \\ ${ }^{2}$ Department of Mathematics and Applied Mathematics, North-West University, \\ 2520 Potchefstroom, South Africa
}

Correspondence should be addressed to M. A. Petersen, mark.petersen@nwu.ac.za

Received 17 June 2008; Revised 15 October 2008; Accepted 17 November 2008

Recommended by Masahiro Yabuta

The ongoing subprime mortgage crisis (SMC) and implementation of Basel II Capital Accord regulation have resulted in issues related to bank valuation and profitability becoming more topical. Profit is a major indicator of financial crises for households, companies, and financial institutions. An SMC-related example of this is the U.S. bank, Wachovia Corp., which reported major losses in the first quarter of 2007 and eventually was bought by Citigroup in September 2008. A first objective of this paper is to value a bank subject to Basel II based on premiums for market, credit, and operational risk. In this case, we investigate the discrete-time dynamics of banking assets, capital, and profit when loan losses and macroeconomic conditions are explicitly considered. These models enable us to formulate an optimal bank valuation problem subject to cash flow, loan demand, financing, and balance sheet constraints. The main achievement of this paper is bank value maximization via optimal choices of loan rate and supply which leads to maximal deposits, provisions for deposit withdrawals, and bank profitability. The aforementioned loan rates and capital provide connections with the SMC. Finally, OECD data confirms that loan loss provisioning and profitability are strongly correlated with the business cycle.

Copyright (c) 2008 C. H. Fouche et al. This is an open access article distributed under the Creative Commons Attribution License, which permits unrestricted use, distribution, and reproduction in any medium, provided the original work is properly cited.

\section{Introduction}

In this paper, we mainly consider bank valuation (Bank value is commonly defined in terms of the market value of the investors equity (stock market capitalization if a company is quoted) plus the market value of the nett financial debt) and profitability when loan losses and macroeconomic conditions are explicitly considered. We note that in the acquisition of bank equity, a valuation gives the stock analyst (possibly acting on behalf of a potential shareholder) an independent estimate of a fair price of the bank's shares. As far as profitability is concerned, we are motivated by the fact that it is a major indicator of financial 
crises for households, companies, and financial institutions. An example of the latter from the subprime mortgage crisis (SMC) that became more apparent in 2007 and 2008 is that both the failure of the Lehmann Brothers investment bank and the acquisition in September 2008 of Merrill Lynch and Bear Stearns by Bank of America and JP Morgan Chase, respectively, were preceded by a decrease in profitability and an increase in the price of loans and loan losses (see Subsection 5.1 for a diagrammatic overview of the SMC). In this paper, we discuss the relationship between our banking models and the SMC as well as the subsequent credit crunch that has had a profound impact on the global banking industry from 2007 onwards. These connections are forged via the bank's risk premium, sensitivity of changes in capital to loan extension, Central Bank base rate, own loan rate, loan demand, loan losses and default rate, loan loss provisions, choice between raising deposits and interbank borrowing, liquidity, profit, as well as bank valuation. In addition, we establish connections between our models and the Basel II Capital Accord. These associations are mainly determined via total bank capital, the bank capital constraint, and the procyclicality of approaches to Basel II Credit Risk.

Loan pricing models usually have components related to the financial funding cost, a risk premium to compensate for the risk of default by the borrower, a premium reflecting market power exercised by the bank and the sensitivity of the cost of capital raised to changes in loans extended. On the other hand, loan losses can be associated with an offsetting expense called the loan loss provision (LLP) which is charged against nett profit. This offset will reduce reported income but has no impact on taxes, although when the assets are finally written off, a tax-deductible expense is created. An important factor influencing loan loss provisioning is regulation and supervision. Measures of capital adequacy are generally calculated using the book values of assets and equity. The provisioning of loans and their associated write offs will cause a decline in these capital adequacy measures, and may precipitate increased regulation by bank authorities. Greater levels of regulation generally entail additional costs for the bank. Currently, this regulation mainly takes the form of the Basel II Capital Accord (see Subsection 5.2.1 for a diagrammatic overview of Basel II; also [1, 2]) that has been implemented on a worldwide basis since 2008 .

The impact of a risk-sensitive framework such as Basel II on macroeconomic stability of banks is an important issue. In this regard, we note that the 1996 Amendment's Internal Models Approach (IMA) determines the capital requirements on the basis of the institutions' internal risk measurement systems. The minimum capital requirement is then the sum of a premium to cover credit risk, general market risk and operational risk. The credit risk premium is made up of risk-weighted loans and the market risk premium is equal to a multiple of the average reported two-week VaRs in the preceding 60 trading days. Banks are required to report daily their value-at-risk $(\mathrm{VaR})$ at a $99 \%$ confidence level over both a one day and two weeks (10 trading days) horizon. In order for a bank to determine their minimum capital requirements they will first decide on a planning horizon. This planning horizon is then partitioned into non-overlapping backtesting-periods, which is in turn divided into nonoverlapping reporting periods. At the start of each reporting period the bank has to report its $\mathrm{VaR}$ for the current period and the actual loss from the previous period. The market risk premium for the current reporting period is then equal to the multiple $m$ of the reported VaR. At the end of each backtesting period, the number of reporting periods in which actual loss exceeded VaR is counted and this determines the multiple $m$ for the next backtesting period according to a given increasing scale. Usually the premium to cover operational risk equals the sum of the premiums for each of eight business lines. The operational risk premium is discussed further in Subsection 2.4 . 
A popular approach to the study of banking valuation and profitability involves a financial system that is assumed to be imperfectly competitive. As a consequence, profits (see, for instance, [3,4]) are ensured by virtue of the fact that the nett loan interest margin is greater than the marginal resource cost of deposits and loans. Besides competition policy, the decisions related to capital structure play a significant role in bank behavior. Here, the relationship between bank capital, credit and macroeconomic activity is of crucial importance. In this regard, it is a widely accepted fact that certain financial variables such as capital, credit, asset prices, profitability and provisioning (also bond spreads, ratings from credit rating agencies, leverage and risk-weighted capital adequacy ratios, other ratios such as write-off/loan ratios and perceived risk) exhibit cyclical tendencies. The cyclicality of a financial variable is related to its relationship with the business cycle or a proxy of the business cycle such as the output gap. Here the output gap is defined as the amount by which a country's output, or GDP, falls short of what it could be given its available resources. In particular, "procyclicality" has become a buzzword in discussions about banking regulation. In essence, the movement in a financial variable is said to be "procyclical" if it tends to amplify business cycle fluctuations. As such, procyclicality is an inherent property of any financial system. A consequence of procyclicality is that banks tend to restrict their lending activity during economic downturns because of their concern about loan quality and the probability of loan defaults. This exacerbates the recession since credit constrained businesses and individuals cut back on their investment activity. On the other hand, banks expand their lending activity during boom periods, thereby contributing to a possible overextension of the economy that may transform an economic expansion into an inflationary spiral. Our contribution emphasizes the cyclicality of bank profitability and provisioning for loan losses.

By way of addressing the issues raised above, we present a two-period discrete-time banking model involving on-balance sheet variables such as assets (cash, bonds, shares, loans, Treasuries and reserves), liabilities (deposits and interbank borrowing), bank capital (shareholder equity, subordinate debt and loan loss reserves) and off-balance sheet items such as intangible assets (see, for instance, $[5,6]$ ). In turn, the aforementioned models enable us to formulate an optimization problem that seeks to establish a maximal value of the bank by a stock analyst by choosing an appropriate loan rate and supply. Under cash flow, loan demand, financing and balance sheet constraints, the solution to this problem also yields a procedure for profit maximization in terms of the loan rate and deposits. Here profits are not only expressed as a function of loan losses but also depend heavily on provisions for loan losses.

\subsection{Relation to previous literature}

In this subsection, we consider the association between our contribution and previously published literature. The issues that we highlight include loan pricing, bank valuation and profitability, the role of bank capital, credit models for monetary policy, macroeconomic activity, cyclicality concerns and discrete-time modeling and optimization as well as the SMC and Basel II.

A number of recent papers on loan pricing are related to our contribution. For instance, $[7,8]$ analyzes and estimates the possible effects of Basel II on the pricing of bank loans. In this regard, the authors discuss two approaches for credit risk capital requirements, viz., the Internal Ratings Based (IRB) and Standardized approaches, and distinguish between retail and corporate customers. As is the case in our contribution, their loan pricing equation is 
based on a model of a bank facing uncertainty operating in an imperfectly competitive loan market. The main results in [8] indicate that high quality corporate and retail customers will enjoy a reduction in loan rates in banks that adopt the IRB approach while high risk customers will benefit by shifting to banks that adopt the Standardized approach. In a perfectly competitive market, the work in [9] considers corporate loans where, as in the model underlying the Basel II IRB approach, a single factor explains the correlation in defaults across firms. The results from [8] also hold true for corporate customers when comparing the IRB and Standardized approaches. In addition, [9] shows that only a very high social cost of bank failure might justifyy the proposed IRB capital charges. A partial reason for this is that nett interest income from performing loans is not considered to be a buffer against loan losses.

The most common method to value a bank is to calculate the present value of the bank's future cash flows. For instance, in [10] a regression model is derived to address the problem of valuing a bank. Similar to this is [11] where a regression model is derived for the change in market value for a specific bank. These papers, and others not mentioned explicitly, discuss activities that add value to the bank making it attractive for potential shareholders. Also, the extent of exposure to emerging markets plays a role in the valuation of the bank. Most of the studies considered, has a statistical background. By contrast, the novelty of our contribution is that we use control laws to find the optimal bank value. The work in [12] claims that profitability by bank function is determined by subtracting all direct and allocable indirect expenses from total gross revenue generated by that function. This computation results in the nett revenue (yield) that excludes cost of funds. From the nett yield the cost of funds is subtracted to determine the nett profit of the bank by function. Coyne represents four major leading functions, viz., investments, real estate mortgage loans, installment loans as well as commercial and agricultural loans. The work in [13] has a discussion on the determinants of commercial bank profitability in common with our paper. The contribution [14] demonstrates by means of technical arguments that banks' profits will not decrease if the growth rate of sales is higher than the absolute growth rate of the bank's own loan rate. This rate will decrease when it is necessary to stimulate growth and provide liquidity.

The most important role of capital is to mitigate the moral hazard problem that results from asymmetric information between banks, depositors and borrowers. In the presence of asymmetric information about the LLP, bank managers may be aware of asset quality problems unknown to outside analysts. Provisioning the assets may convey a clearer picture regarding the worth of these assets and precipitate a (negative) market adjustment. The Modigliani-Miller theorem forms the basis for modern thinking on capital structure (see [15]). In an efficient market, their basic result states that, in the absence of taxes, insolvency costs and asymmetric information, the bank value is unaffected by how it is financed. In this framework, it does not matter if bank capital is raised by issuing equity or selling debt or what the dividend policy is. By contrast, in our contribution, in the presence of loan market frictions, the bank value is dependent on its financial structure (see, for instance, [16-18]). In this case, it is well-known that the bank's decisions about lending and other issues may be driven by the capital adequacy ratio (CAR) (see, for instance, [19-23]). Further evidence of the impact of capital requirements on bank lending activities are provided by $[24,25]$. A new line of research into credit models for monetary policy has considered the association between bank capital and loan demand and supply (see, for instance, [26-31]). This credit channel is commonly known as the bank capital channel and propagates that a change in interest rates can affect lending via bank capital. 
We also discuss the effect of macroeconomic activity on a bank's capital structure and lending activities (see, for instance, [32]). With regard to the latter, for instance, there is considerable evidence to suggest that macroeconomic conditions impact the probability of default and loss given default on loans (see, for instance, [32, 33]). Our contribution has a close connection with [29] via our interest in how cyclicality relates to profitability and provisioning. In particular, the fact that provisioning (profitability) behaves procyclically by falling (rising) during economic booms and rising (falling) during recessions (see, for instance, [27-29, 34-36]) is incorporated in our models. The working paper [37] provides us with a direct connection between the present contribution and the SMC. In the said paper, it is claimed that the rise and fall of the subprime mortgage market follows a classic credit boombust scenario in which unsustainable growth leads to the collapse of the market. In other words, this means that procyclicality of bank credit has led to the crisis in credit markets-a situation that we allow for in our model.

Several discussions related to discrete-time optimization problems for banks have recently surfaced in the literature (see, for instance, $[18,22,32,38]$ ). Also, some recent papers using dynamic optimization methods in analyzing bank regulatory capital policies include [39] for Basel II and [40-42] for Basel market risk capital requirements. In [22], a discrete-time dynamic banking model of imperfect competition is presented, where the bank can invest in a prudent or a gambling asset. For both these options, a maximization problem that involves bank value is formulated. On the other hand, [38] examines a problem related to the optimal risk management of banks in a continuous-time stochastic dynamic setting. In particular, the authors minimize market and capital adequacy risk that involves the safety of the assets held and the stability of sources of capital, respectively (see, also, [43]).

The working paper [37] explains the fundamentals of the SMC in some detail. A model that has become important during this crisis is the Diamond-Dybvig model (see, for instance, $[44,45])$. Despite the fact that these contributions consider a simpler model than ours, they are able to explain important features of bank liquidity that reflect reality. The quarterly reports $[46,47]$ of the Federal Deposit Insurance Corporation (FDIC) intimate that profits decreased from $\$ 35.6$ billion to $\$ 19.3$ billion during the first quarter of 2008 versus the previous year, a decline of $46 \%$.

\subsection{Outline of the paper}

We extend aspects of the literature mentioned in Subsection 1.1 in several directions. Firstly, taking our lead from Basel II, by contrast to [29], the risk-weight for the assets appearing on and off the balance sheet may vary with time. In the second place, in the spirit of the Basel II, we incorporate market, credit and operational risk at several levels in our discrete-time models. Here we recognize that most contributions (see, for instance, [41]) only consider market and credit risk as in the previous regulatory paradigm (Basel I Capital Accord). Furthermore, we incorporate both Treasuries and reserves as part of the provisions for deposit withdrawals whereas [29] only discusses the role of Treasuries. Fourthly, we include loan losses and its provisioning as an integral part of our analysis (compare with $[29,36]$ ). Also, we provide substantive evidence of the procyclicality of credit, profitability and provisioning for OECD countries (compare with [27, 28, 34, 35]). In the sixth place, we recognize the important role that intangible assets play in determining bank profit and valuation (compare with $[5,6])$. Also, we determine the value of a bank subject to capital requirements based on reported Value-at-Risk (VaR) and operational measures, as in the Basel Committee's Internal 
Models Approach (see, for instance, [48]). Finally, we forge connections between our banking models and the SMC as well as Basel II. follows.

The main problems to emerge from the previous paragraph can be formulated as

Problem 1 (modeling bank valuation and loan losses). Can we model the value of a bank and quantify losses from its lending activities in discrete-time? (Sections 2 and 3). Can we confirm that these models are realistic in some respects? (Section 4).

Problem 2 (optimal bank valuation problem). Which decisions about loan rates, deposits and Treasuries must be made in order to attain an optimal bank value for a shareholder? (Theorem 3.1 in Section 3).

Problem 3 (connections with the SMC and Basel II). How do the banking models developed in our paper relate to the SMC and Basel II Capital Accord? (Section 5).

The paper is structured as follows. In Subsection 2.1 of Section 2, we describe general bank assets (shares, bonds, cash, intangible assets, Treasuries and reserves). Also, in this section, we construct models for bank loan supply, demand and losses as well as for provisions for loan losses (see Subsections 2.2). In Section 3, we present models for capital (with a risk-based capital requirement) and profit (Subsections 3.1 and 3.2). A description of how a bank may be valued by a stock analyst for a shareholder is given in Subsection 3.3, while an optimal valuation problem is formulated and solved in Subsection 3.4. By way of corroborating our choice of models, in Section 4, historical evidence (see Subsection 4.1) and illustrative examples (see Subsection 4.2) reflecting the cyclicality of provisions and profitability and the correlation between these financial variables, respectively, are presented. Aspects of the relationships between bank valuation and the SMC as well as Basel II are analyzed in Section 5. Next, Section 6 offers a few concluding remarks and topics for possible future research. Finally, relevant appendices are provided in the appendices.

\section{Discrete-time banking model}

Throughout, we suppose that $\left(\Omega, \mathbf{F},\left(\mathscr{F}_{t}\right)_{t \geq 0}, \mathbf{P}\right)$ is a filtered probability space. Also, we deal with an individual bank that precommits to a loan quantity via its dividends policy in the $t$ th period, which is subsequently followed by the loan rate competition in the $(t+1)$ th period. As is well-known, the bank balance sheet consists of assets (uses of funds) and liabilities (sources of funds) that are balanced by bank capital (see, for instance, [17]) according to the well-known relation

$$
\text { Total assets }(A)=\text { Total liabilities }(\Gamma)+\text { Total bank capital }(K) \text {. }
$$

In period $t$, the main on-balance sheet items in (2.1) can specifically be identified as

$$
\begin{gathered}
A_{t}=\Lambda_{t}^{m}+W_{t}+C_{t}+S_{t}+B_{t}, \quad W_{t}=\mathrm{T}_{t}+R_{t} ; \\
\Gamma_{t}=D_{t}+B_{t} ; \quad K_{t}=n_{t} E_{t-1}+O_{t}+R_{t}^{l},
\end{gathered}
$$

where $\Lambda^{m}, C, S, B, \mathrm{~T}, R, D, \mathrm{~B}, n, E, O$, and $R^{l}$ are the market value of short- and long-term loans, cash, short- and long-term securities, bonds, Treasuries, reserves, deposits, interbank 
borrowing including borrowing from the Central Bank, number of shares, market price of the bank's common equity, subordinate debt and loan loss reserves, respectively.

The balance sheet reflects the fact that banks are active in the primary market by raising deposits, $D$, from and extending credit, $\Lambda$, to the public. Also, banks operate in the secondary market in order to bridge the gap between surpluses and deficits in its reserves, $R$ and $R^{l}$. This involves transactions with other commercial banks (interbank lending), with the Central Bank (monetary loans or deposits with the Central Bank) and Treasury (buying and selling Treasury securities) as well as in the financial markets (buying and selling securities). Also the bank holds capital, $K$, as required by the regulator, which serves as a cushion against unexpected losses (primarily from its loan portfolio).

\subsection{General bank assets}

In this subsection, we discuss on- and off-balance sheet bank assets such as shares, bonds and cash, Treasuries, reserves and intangible assets.

\subsubsection{Shares}

Of the first three general bank asset classes, shares, $S$, have historically been the most prominent performers over the long term. Since the returns from shares usually exceed the returns from both bonds and cash and have significantly outpaced inflation, they are important to a portfolio for growth of capital over time. Over the short term, however, shares can be volatile and as a result there is regulation related to banks holding shares. In the sequel, the rate of return on shares in the $t$ th period, $S_{t}$, is denoted by $r_{t}^{S}$.

\subsubsection{Bonds}

Whereas shares represent equity, or part ownership of the companies that issue them, bonds, $B$, represent debt. Municipalities and governments all use bonds as a way to raise cash. When banks buy bonds, they are lending money to the issuer in exchange for fixed interest payments over a set number of years and a promise to pay the original amount back in the future. Bonds are valuable to banks more for the income they provide than for growth potential. Since the income they pay is fixed it is generally reliable and steady. The primary risk in bond market investing comes from interest rate changes. When interest rates rise, a bond's market value decreases. Another potential risk of owning bonds is default, which can occur when the bond issuer is no longer able either to pay the interest or repay the principal. The latter is negated by the fact that banks mainly buy government and municipal bonds with a very small likelihood of default. Below, the rate of return on bonds in the th period, $B_{t}$, is denoted by $r_{t}^{B}$.

\subsubsection{Cash}

Cash, $C$, is a term assigned to very short-term savings instruments such as money market securities. These investments can be used to meet near-term financial needs or to protect a portion of an investment portfolio from price fluctuation. The downside of cash securities is that they offer no real opportunities for long-term growth. Though economic conditions and factors such as changing interest rates can impact both stocks and bonds, these markets perform independently of each other and can therefore serve as a balance within the portfolio of a bank. In the sequel, the rate of return on cash in the $t$ th period, $C_{t}$, is denoted by $r_{t}^{C}$. 


\subsubsection{Intangible assets}

In the contemporary banking industry, shareholder value is often created by intangible assets which consist of patents, trademarks, brand names, franchises and economic goodwill. Such goodwill consists of the intangible advantages a bank has over its competitors such as an excellent reputation, strategic location, business connections, and so forth. In addition, such assets can comprise a large part of the bank's total assets and provide a sustainable source of wealth creation. Intangible assets are used to compute Tier 1 bank capital and have a risk-weight of $100 \%$ according to Basel II regulation (see Table 1). In practice, valuing these off-balance sheet items constitutes one of the principal difficulties with the process of bank valuation by a stock analyst. The reason for this is that intangibles may be considered to be "risky" assets for which the future service potential is hard to measure. Despite this, our model assumes that the measurement of these intangibles is possible (see, for instance, $[5,6]$ ).

In reality, valuing this off-balance sheet item constitutes one of the principal difficulties with the process of bank valuation (see, for instance, $[5,6]$ ). Nevertheless, we denote the value of intangible assets, in the $t$ th period, by $I_{t}$ and the return on these assets by $r_{t}^{I} I_{t}$, where

$$
r_{t}^{I}=\frac{I_{t+1}-I_{t}}{I_{t}}
$$

\subsubsection{Treasuries}

Treasuries in the $t$ th period, $\mathrm{T}_{t}$, coincide with securities that are issued by national Treasuries at a rate denoted by $r^{\mathrm{T}}$. In essence, they are the debt financing instruments of the federal government. There are four types of Treasuries, viz., Treasury bills, Treasury notes, Treasury bonds and savings bonds. All of the Treasury securities besides savings bonds are very liquid and are heavily traded on the secondary market.

\subsubsection{Reserves}

Bank reserves are the deposits held in accounts with a national institution (for instance, the Federal Reserve) plus money that is physically held by banks (vault cash). Such reserves are constituted by money that is not lent out but is earmarked to cater for withdrawals by depositors. Since it is uncommon for depositors to withdraw all of their funds simultaneously, only a portion of total deposits may be needed as reserves. As a result of this description, we may introduce a reserve-deposit ratio, $\gamma$, for which

$$
R_{t}=\gamma D_{t}
$$

The bank uses the remaining deposits to earn profit, either by issuing loans or by investing in assets such as Treasuries and stocks.

\subsection{Loans}

In this subsection, we consider loan and their supply and demand, loan losses and the provisioning for such losses. 


\subsubsection{Loans and their demand and supply}

We suppose that, after providing liquidity, the bank lends in the form of $t$ th period loans, $\Lambda_{t}$, at the bank's own loan rate, $r_{t}^{\Lambda}$. This loan rate, for profit maximizing banks, is determined by the risk premium (or yield differential), given by

$$
Q_{t}=r_{t}^{\Lambda}-r_{t}
$$

the industry's market power as determined by its concentration, $N$, the market elasticity of demand for loans, $\eta$, base rate, $r_{t}$, the marginal cost of raising funds in the secondary market, $c^{\mathrm{rw}}$, and the product of the cost of elasticity (equity) raised, $c^{E}$, and the sensitivity of the required capital to changes in the amount of loans extended,

$$
\frac{\partial K}{\partial \Lambda}
$$

In this situation, we may express the bank's own loan rate, $r^{\Lambda}$, as

$$
r_{t}^{\Lambda}=\rho+\left(1+r_{t}\right) \frac{N}{\eta}+c^{\mathrm{rw}}+c^{E} \frac{\partial K}{\partial \Lambda}+\mathbf{E}[l]
$$

where

$$
N=\sum_{i=1}^{n} S_{i}^{2}
$$

is the Herfindahl-Hirschman index of the concentration in the loan market,

$$
S_{i}=\frac{\Lambda_{i}}{\Lambda}
$$

is the market share of bank $i$ in the loan market, but in our contribution we only use one bank, therefore $N=1$ and

$$
\eta=-\frac{\partial \Lambda}{\partial r_{t}^{\Lambda}} \frac{r_{t}^{\Lambda}}{\Lambda}
$$

is the elasticity of demand for loans. Also, in our model, besides the risk premium, we include $\mathbf{E}[l]$ which constitutes the amount of provisioning that is needed to match the average expected losses faced by the loans.

In this paragraph, we provide a brief discussion of loan demand and supply. Taking our lead from the equilibrium arguments in [30], we denote both these credit price processes by $\Lambda=\left\{\Lambda_{t}\right\}_{t \geq 0}$. In this case, the bank faces a Hicksian demand for loans given by

$$
\Lambda_{t}=l_{0}-l_{1} r_{t}^{\Lambda}+l_{2} \mathrm{M}_{t}+\sigma_{t}^{\Lambda}
$$


We note that the loan demand in (2.11) is an increasing function of $\mathrm{M}$ and a decreasing function of $r_{t}^{\Lambda}$. Also, we assume that $\sigma_{t}^{\Lambda}$ is the random shock to the loan demand with support $[\underline{\Lambda}, \bar{\Lambda}]$ that is independent of an exogenous stochastic variable, $x_{t}$, to be characterized below. In addition, we suppose that the loan supply process, $\Lambda$, follows the first-order autoregressive stochastic process

$$
\Lambda_{t+1}=\mu_{t}^{\Lambda} \Lambda_{t}+\sigma_{t+1}^{\Lambda}
$$

where $\mu_{t}^{\Lambda}=r_{t}^{\Lambda}-c^{\Lambda}-r^{d}\left(\mathrm{M}_{t}\right)$ and $\sigma_{t+1}^{\Lambda}$ denotes zero-mean stochastic shocks to loan supply.

Remark 2.1 (loan demand and supply). Banks respond differently to shocks that affect loan demand, $\Lambda$, when the minimum capital requirements are calculated by using riskweighted assets. In the Hicksian case, these responses are usually sensitive to macroeconomic conditions that are related to the term $l_{2} \mathrm{M}_{t}$ in (2.11). Here we may broaden the analysis quite considerably by supposing that $\mathrm{M}=\left\{\mathrm{M}_{t}\right\}_{t \geq 0}$ follows the first-order autoregressive stochastic process

$$
\mathrm{M}_{t+1}=\mu^{\mathrm{M}} \mathrm{M}_{t}+\sigma_{t+1}^{\mathrm{M}}
$$

where $\sigma_{t+1}^{\mathrm{M}}$ denotes zero-mean stochastic shocks to macroeconomic activity.

\subsubsection{Loan losses and provisioning}

The bank's investment in loans may yield substantial returns but may also result in loan losses. In line with reality, our dynamic bank model allows for loan losses for which provision can be made. Total loan loss provisions, $P$, mainly affects the bank in the following ways. Reported nett profit will be less for the period in which the provision is taken. If the bank eventually writes off the asset, the write off will reduce taxes and thus increase the banks cash flows. Empirical evidence suggests that $P$ is affected by macroeconomic activity, $\mathrm{M}$, so that the notation $P\left(\mathrm{M}_{t}\right)$ for period $t$ loan loss provisioning is in order (see, for instance, [34, 35]).

For the value of the aggregate loan losses, $L$, and the default rate, $r^{d}$, we have that

$$
L\left(\mathrm{M}_{t}\right)=r^{d}\left(\mathrm{M}_{t}\right) \Lambda_{t}
$$

where $r^{d} \in[0,1]$ increases when macroeconomic conditions deteriorate according to

$$
0 \leq r^{d}\left(\mathrm{M}_{t}\right) \leq 1, \quad \frac{\partial r^{d}\left(\mathrm{M}_{t}\right)}{\partial \mathrm{M}_{t}}<0
$$

We note that the above description of the loan loss rate is consistent with empirical evidence that suggests that bank losses on loan portfolios are correlated with the business cycle under any capital adequacy regime (see, for instance, [34-36, 49]).

As was mentioned before, the contribution [34] (see, also, [36, 49]) highlights the fact that normally provisions for expected loan losses, $(\alpha \rho+\mathbf{E}[l]) \Lambda_{t}$, where $0 \leq \alpha \leq 1$ and $\rho$ is the risk premium from (2.5), and loan loss reserves, $R^{l}$, act as buffers against expected and unexpected loan losses, respectively. Firstly, we have to distinguish between 
total provisioning for loan losses, $P$, and loan loss reserves, $R^{l}$. Provisioning is a decision made by bank management about the size of the buffer that must be set aside in a particular time period in order to cover loan losses, $L$. However, not all of $P$ may be used in a time period with the amount left over constituting loan loss reserves, $R^{l}$, so that for period $t$ we have

$$
R_{t}^{l}=P\left(\mathrm{M}_{t}\right)-L\left(\mathrm{M}_{t}\right), \quad P>L
$$

Our model for provisioning in period $t+1$ can be taken to be

$$
P\left(\mathrm{M}_{t+1}\right)= \begin{cases}(\alpha \varrho+\mathrm{E}[l]) \Lambda_{t}, & \text { for } P>L \text { Expected losses } \\ (\alpha \varrho+\mathrm{E}[l]) \Lambda_{t}+R_{t+1}^{l}, & \text { for } P \leq L \text { Expected losses + Unexpected losses }\end{cases}
$$

We note that our model determines the provisions for period $t+1$ in the $t$ th period which is a reasonable assumption. Our suspicion is that provisioning, $P$, is a decreasing function of current macroeconomic conditions, $\mathrm{M}$, so that

$$
\frac{\partial P\left(\mathrm{M}_{t}\right)}{\partial \mathrm{M}_{t}}<0
$$

This claim has resonance with the idea of procyclicality where we expect the provisioning to decrease during booms, when macroeconomic activity increases. By contrast, provisioning may increase during recessions because of an elevated probability of default and/or loss given default on loans. This suspicion is confirmed in Section 4 where empirical data from OECD countries comparing macroeconomic activity (via the output gap) and provisioning (via the provisions-to-total assets ratio) is examined.

\subsection{Liabilities}

In this subsection, we consider deposits and provisioning for deposit withdrawals as well as interbank borrowing.

\subsubsection{Deposits}

The bank takes deposits, $D_{t}$, at a constant marginal cost, $c^{D}$, that may be associated with cheque clearing and bookkeeping. It is assumed that deposit taking is not interrupted even in times when the interest rate on deposits or deposit rate, $r_{t}^{D}$, is less than the interest rate on Treasuries or bond rate, $r_{t}^{\mathrm{T}}$, We suppose that the dynamics of the deposit rate process, $r^{D}=\left\{r_{t}^{D}\right\}_{t \geq 0}$, is determined by the first-order autoregressive stochastic process

$$
r_{t+1}^{D}=\mu^{r^{D}} r_{t}^{D}+\sigma_{t+1}^{r^{D}}
$$

where $\sigma_{t+1}^{r^{D}}$ is zero-mean stochastic shocks to the deposit rate.

Remark 2.2 (deposit rate and monetary policy). In some quarters, the deposit rate, $r^{D}$, is considered to be a strong approximation of bank monetary policy. Since such policy is 
usually affected by macroeconomic activity, $\mathrm{M}$, we expect the aforementioned items to share an intimate connection. However, in our analysis, we assume that the shocks $\sigma_{t+1}^{D}$ and $\sigma_{t+1}^{M}$ to $r^{D}$ and $\mathrm{M}$, respectively, are uncorrelated. Essentially, this means that a precise monetary policy is lacking in our bank model. This interesting relationship is the subject of further investigation.

\subsubsection{Provisioning for deposit withdrawals}

We have to consider the possibility that unanticipated deposit withdrawals will occur. By way of making provision for these withdrawals, the bank is inclined to hold Treasuries and reserves that are both very liquid. In our contribution, we assume that the unanticipated deposit withdrawals, $u$, originates from the probability density function, $f(u)$, that is independent of time. For sake of argument, we suppose that the unanticipated deposit withdrawals have a uniform distribution with support $[0, \bar{D}]$ so that the cost of liquidation, $c^{l}$, or additional external funding is a quadratic function of the sum of Treasuries and reserves, $W$. In addition, for any $t$, if we have that

$$
u>W_{t}
$$

where $W_{t}=\mathrm{T}_{t}+R_{t}$, then bank assets are liquidated at some penalty rate, $r_{t}^{p}$. In this case, the cost of deposit withdrawals is

$$
c^{w}\left(W_{t}\right)=r_{t}^{p} \int_{W_{t}}^{\infty}\left[u-W_{t}\right] f(u) d u=\frac{r_{t}^{p}}{2 \bar{D}}\left[\bar{D}-W_{t}\right]^{2}
$$

Remark 2.3 (deposit withdrawals and bank liquidity). A vital component of the process of deposit withdrawal is liquidity. The level of liquidity in the banking sector affects the ability of banks to meet commitments as they become due (such as deposit withdrawals) without incurring substantial losses from liquidating less liquid assets. Liquidity, therefore, provides the defensive cash or near-cash resources to cover banks' liabilities.

\subsubsection{Borrowing from other banks}

Interbank borrowing including borrowing from the Central Bank provides a further source of funds. In the sequel, the amount borrowed from other banks is denoted by B, while the interbank borrowing rate (for instance, known as the Libor rate in the United Kingdom) and marginal borrowing costs are denoted by $r^{B}$ and $c^{B}$, respectively. Of course, when our bank borrows from the Central Bank, we have $r^{B}=r$, where $r$ is the base rate appearing in (2.5). Another important issue here is the comparison between the cost of raising and holding deposits, $\left(r^{D}+c^{D}\right) D$, and the cost of interbank borrowing, $\left(r^{\mathrm{B}}+c^{\mathrm{B}}\right) \mathrm{B}$. In this regard, a bank in need of capital would have to choose between raising deposits and borrowing from other banks on the basis of overall cost. In other words, the expression

$$
\min \left\{\left(r^{D}+c^{D}\right) D,\left(r^{\mathrm{B}}+c^{\mathrm{B}}\right) \mathrm{B}\right\}
$$


is of some consequence. For sake of argument, in the sequel, we assume that

$$
\left(r^{D}+c^{D}\right) D=\min \left\{\left(r^{D}+c^{D}\right) D,\left(r^{\mathrm{B}}+c^{\mathrm{B}}\right) \mathrm{B}\right\} .
$$

\subsection{Operational risk}

The Basel II framework outlines three quantitative approaches for determining an operational risk capital premium: the Basic Indicator approach, the Standardized approach, and the Advanced Measurement approach. The Basic Indicator and the Standardized approaches are simple and generate results on the basis of predetermined multipliers. More specifically, the capital premium for operational risk, under the Standardized approach outlined in the Basel II, may be expressed as

$$
0=\max \left[\sum_{k=1}^{8} \beta_{k} g_{k}, 0\right]
$$

where, $g_{1-8}$ is three-year average of gross income for each of eight business lines, and $\beta_{1-8}$ is fixed percentage relating level of required capital to level of gross income for each of eight business lines.

The $\beta$-values for operational risk are provided in the document [1].

\section{Bank valuation}

In this section, we discuss bank regulatory capital, binding capital constraints, retained earnings and the valuation of a bank by a stock analyst.

\subsection{Bank regulatory capital}

In this subsection, we provide a general description of bank capital and then specify the components of total bank capital that we use in our study.

\subsubsection{General description of bank capital}

According to Basel II, three types of capital can be identified, viz., Tier 1, 2 and 3 capital, which we describe in more detail below. Tier 1 capital comprises ordinary share capital (or equity) of the bank and audited revenue reserves, for example, retained earnings less current year's losses, future tax benefits and intangible assets (for more information see, for instance, $[5,6])$. Tier 1 capital or core capital acts as a buffer against losses without a bank being required to cease trading. Tier 2 capital includes unaudited retained earnings; revaluation reserves; general provisions for bad debts (e.g., loan loss reserves); perpetual cumulative preference shares (i.e., preference shares with no maturity date whose dividends accrue for future payment even if the bank's financial condition does not support immediate payment) and perpetual subordinated debt (i.e., debt with no maturity date which ranks in priority behind all creditors except shareholders). Tier 2 capital or supplementary capital can absorb losses in the event of a wind-up and so provides a lesser degree of protection to depositors. Tier 3 capital consists of subordinated debt with a term of at least 5 years and redeemable preference shares which may not be redeemed for at least 5 years. Tier 3 capital can be 
Table 1: Risk categories, risk-weights and representative items.

\begin{tabular}{lcc}
\hline Risk category & Risk-weight & Banking items \\
\hline 1 & $0 \%$ & Cash, bonds, treasuries, reserves \\
2 & $20 \%$ & Shares \\
3 & $50 \%$ & Home loans \\
4 & $100 \%$ & Intangible assets \\
5 & $100 \%$ & Loans to private agents \\
\hline
\end{tabular}

used to provide a hedge against losses caused by market risks if Tier 1 and Tier 2 capital are insufficient for this.

\subsubsection{Specific components of total bank capital}

For the purposes of our study, regulatory capital, $K$, is the book value of bank capital defined as the difference between the accounting value of the assets and liabilities. More specifically, Tier 1 capital is represented by period $t-1$ 's market value of the bank equity, $n_{t} E_{t-1}$, where $n_{t}$ is the number of shares and $E_{t}$ is the period $t$ market price of the bank's common equity. Tier 2 capital mainly consists of subordinate debt, $O_{t}$, that is subordinate to deposits and hence faces greater credit risk and loan loss reserves, $R_{t}^{l}$. Subordinate debt issued in period $t-1$ are represented by a one-period bond that pays an interest rate, $r^{O}$. Also, we assume that loan loss reserves held in period $t-1$ changes at the rate, $r^{R^{l}}$. Tier 3 capital is not considered at all. In the sequel, we take the bank's total regulatory capital, $K$, in period $t$ to be

$$
K_{t}=n_{t} E_{t-1}+O_{t}+R_{t}^{l}
$$

For $K_{t}$ given by (3.1), we obtain the balance sheet constraint

$$
W_{t}=D_{t}+B_{t}-\Lambda_{t}-C_{t}-B_{t}-S_{t}+K_{t}
$$

\subsubsection{Binding capital constraints}

In order to describe the binding capital constraint, we consider risk-weighted assets (RWAs) that are defined by placing each on- and off-balance sheet item into a risk category. The more risky assets are assigned a larger weight. Table 1 provides a few illustrative risk categories, their risk-weights and representative items.

As a result, RWAs are a weighted sum of the various assets of the banks. In the sequel, we denote the risk-weight on intangible assets, cash, bonds, shares, loans, Treasuries and reserves by $\omega^{I}, \omega^{C}, \omega^{B}, \omega^{S}, \omega^{\Lambda}, \omega^{\mathrm{T}}$, and, $\omega^{R}$, respectively. In particular, we can identify a special risk-weight on loans, $\omega^{\Lambda}=\omega\left(\mathrm{M}_{t}\right)$, that is a decreasing function of current macroeconomic conditions so that

$$
\frac{\partial w\left(\mathrm{M}_{t}\right)}{\partial \mathrm{M}_{t}}<0
$$


This is in line with the procyclical notion that during booms, when macroeconomic activity increases, the risk-weights will decrease. On the other hand, during recessions, risk-weights may increase because of an elevated probability of default and/or loss given default on loans. The bank capital constraint is defined by the inequality

$$
K_{t} \geq \rho\left(a_{t}+12.5(m \mathrm{VaR}+0)\right)
$$

where

$$
a_{t}=\omega^{I} I_{t}+\omega^{C} C_{t}+\omega^{B} B_{t}+\omega^{S} S_{t}+\omega^{\Lambda} \Lambda_{t}+\omega^{\mathrm{T}} \mathrm{T}_{t}+\omega^{R} R_{t}
$$

and $\rho \approx 0.08$. The formulation of (3.4) and the choice of this particular value for $\rho$ is informed by page 12 of "Part 2: The First Pillar-Minimum Capital Requirements" of [2]. This excerpt from the document outlining Basel II states that

"Part 2 presents the calculation of the total minimum capital requirements for credit, market and operational risk. The capital ratio is calculated using the definition of regulatory capital and risk-weighted assets. The total capital ratio must be no lower that $8 \%$.... Total risk-weighted assets are determined by multiplying the capital requirements for market risk and operational risk by 12.5 (i.e., the reciprocal of the minimum capital ratio of $8 \%$ ) and adding the resulting figures to the sum of risk-weighted assets for credit risk."

Also, $m$ VaR and 0 in (3.4) are as described in Sections 1 and 2 of this paper, respectively.

In accordance with Table 1, if we assume that the risk-weights associated with intangible assets, shares, cash, bonds, Treasuries, reserves and loans may be taken to be $\omega^{I} \neq 0, \omega^{S} \neq 0, \omega^{C}=\omega^{B}=\omega^{\mathrm{T}}=\omega^{R}=0$ and $\omega^{\Lambda}=\omega\left(\mathrm{M}_{t}\right)$, respectively, then equation (3.4) becomes the capital constraint

$$
K_{t} \geq \rho\left[\omega\left(\mathrm{M}_{t}\right) \Lambda_{t}+\omega^{I} I_{t}+\omega^{S} S_{t}+12.5(m \mathrm{VaR}+0)\right]
$$

\subsection{Profits and retained earnings}

In this subsection, we discuss profits and its relation to retained earnings.

\subsubsection{Profits}

We assume that (2.4) holds. As far as profit, $\Pi$, is concerned, we use the basic fact that profits can be characterized as the difference between income and expenses that are reported in the bank's income statement. In our contribution, income is solely constituted by the returns on intangible assets, $r_{t}^{I} I_{t}$, cash, $r_{t}^{C} C_{t}$, bonds, $r_{t}^{B} B_{t}$, shares, $r_{t}^{S} S_{t}$, loans, $r_{t}^{\Lambda} \Lambda_{t}$, and Treasuries, $r_{t}^{\mathrm{T}} \mathrm{T}_{t}$. Furthermore, we assume that the level of macroeconomic activity is denoted by $\mathrm{M}_{t}$. In our case we consider the cost of monitoring and screening of loans and capital, $c^{\Lambda} \Lambda_{t}$, interest paid to depositors, $r_{t}^{D} D_{t}$, the cost of taking deposits, $c^{D} D_{t}$, the cost of deposit withdrawals, $c^{w}\left(W_{t}\right)$, the value of loan losses, $L\left(\mathrm{M}_{t}\right)$, and total loan loss provisions, $P\left(\mathrm{M}_{t}\right)$ as expenses, in period $t$. Here $r^{D}$ and $c^{D}$ are the deposit rate and marginal cost of deposits, respectively. Summing all 
the costs mentioned to operating costs and supposing that (2.13) holds and that $W_{t}=\mathrm{T}_{\mathrm{t}}+\gamma D_{t}$, then the bank's profits are given by the expression

$$
\begin{aligned}
\Pi_{t}= & \left(r_{t}^{\Lambda}-c^{\Lambda}-r^{d}\left(\mathrm{M}_{t}\right)\right) \Lambda_{t}+r_{t}^{\mathrm{T}} W_{t}+r_{t}^{I} I_{t}+r_{t}^{\mathrm{C}} C_{t}+r_{t}^{B} B_{t}+r_{t}^{S} S_{t} \\
& -\left(r_{t}^{D}+c^{D}\right) D_{t}-c^{w}\left(W_{t}\right)-P\left(\mathrm{M}_{t}\right)-r_{t}^{\mathrm{T}} r D_{t},
\end{aligned}
$$

where $r^{I}, r^{C}, r^{B}$ and $r^{S}$ are the rates of return of the intangible assets, cash, bonds and shares, respectively. Furthermore, by considering (2.17) and (3.7), we suspect that profit, $\Pi$, is an increasing function of current macroeconomic conditions, $M$, so that

$$
\frac{\partial \Pi_{t}}{\partial \mathrm{M}_{t}}>0
$$

This is connected with procyclicality where we expect profitability to increase during booms, when macroeconomic activity increases. By contrast, profitability may decrease during recessions because of, among many other factors, an increase in provisioning (see (3.7)). Importantly, examples of this phenomenon is provided in Subsection 4.2 of Section 4 where the correlation between macroeconomic activity, provisioning and profitability is established.

\subsubsection{Profits and its relationship with retained earnings}

To establish the relationship between bank profitability and the Basel Accord a model of bank financing is introduced that is based on [26]. We know that bank profits, $\Pi_{t}$, are used to meet the bank's commitments that include dividend payments on equity, $n_{t} d_{t}$, interest and principal payments on subordinate debt, $\left(1+r_{t}^{O}\right) O_{t}$. The retained earnings, $E_{t}^{r}$, subsequent to these payments may be computed by using

$$
\Pi_{t}=E_{t}^{r}+n_{t} d_{t}+\left(1+r_{t}^{O}\right) O_{t}
$$

In standard usage, retained earnings refer to earnings that are not paid out in dividends, interest or taxes. They represent wealth accumulating in the bank and should be capitalized in the value of the bank's equity. Retained earnings also are defined to include bank charter value income. Normally, charter value refers to the present value of anticipated profits from future lending.

In each period, banks invest in fixed assets (including buildings and equipment) which we denote by $F_{t}$. The bank is assumed to maintain these assets throughout its existence so that the bank must only cover the costs related to the depreciation of fixed assets, $\Delta F_{t}$. These activities are financed through retaining earnings and the eliciting of additional debt and equity, so that

$$
\Delta F_{t}=E_{t}^{r}+\left(n_{t+1}-n_{t}\right) E_{t}+O_{t+1}+R_{t+1}^{l}
$$

We can use (3.9) and (3.10) to obtain an expression for bank capital of the form

$$
K_{t+1}=n_{t}\left(d_{t}+E_{t}\right)+\left(1+r_{t}^{O}\right) O_{t}-\Pi_{t}+\Delta F_{t}
$$

where $K_{t}$ is defined by(3.1). 


\subsection{Bank valuation for a shareholder}

If the expression for retained earnings given by (3.9) is substituted into (3.10), the nett cash flow generated by the bank for a shareholder is given by

$$
N_{t}=\Pi_{t}-\Delta F_{t}=n_{t} d_{t}+\left(1+r_{t}^{O}\right) O_{t}-K_{t+1}+n_{t} E_{t}
$$

In addition, we have the relationship

Bank value for a shareholder $=$ Nett cash flow + Ex-dividend bank value

This translates to the expression

$$
N_{t}+K_{t+1}
$$

where $K_{t}$ is defined by (3.1). Furthermore, the stock analyst evaluates the expected future cash flows in $j$ periods based on a stochastic discount factor, $\delta_{t, j}$ such that the value of the bank is

$$
N_{t}+\mathbf{E}_{t}\left[\sum_{j=1}^{\infty} \delta_{t, j} N_{t+j}\right] .
$$

\subsection{Optimal bank value for a shareholder}

In this subsection, we make use of the modeling of assets, liabilities and capital of the preceding section to solve an optimal bank valuation problem.

\subsubsection{Statement of the optimal bank valuation problem}

Suppose that the bank valuation performance criterion, $J$, at $t$ is given by

$$
\begin{aligned}
J_{t}= & \Pi_{t}+l_{t}\left[K_{t}-\rho\left(\omega\left(\mathrm{M}_{t}\right) \Lambda_{t}+\omega^{I} I_{t}+\omega^{S} S_{t}+12.5(m \mathrm{VaR}+0)\right)\right] \\
& -c_{t}^{\mathrm{dw}}\left[K_{t+1}\right]+\mathbf{E}_{t}\left[\delta_{t, 1} V\left(K_{t+1}, x_{t+1}\right)\right],
\end{aligned}
$$

where $l_{t}$ is the Lagrangian multiplier for the total capital constraint, $K_{t}$ is defined by (3.1), $\mathbf{E}_{t}[\cdot]$ is the expectation conditional on the bank's information at time $t$ and $x_{t}$ is the deposit withdrawals in period $t$ with probability distribution $f\left(x_{t}\right)$. Also, $c_{t}^{\mathrm{dw}}$ is the deadweight cost of total capital that consists of equity, subordinate debt and loan loss reserves. The optimal bank valuation problem is to maximize the bank value given by (3.15). We can now state the optimal valuation problem as follows.

Problem 4 (statement of the optimal bank valuation problem). Suppose that the total capital constraint and the performance criterion, $J$, are given by (3.6) and (3.16), respectively. The 
optimal bank valuation problem is to maximize the value of the bank given by (3.15) by choosing the loan rate, deposits and regulatory capital for

$$
V\left(K_{t}, x_{t}\right)=\max _{r_{t}^{\wedge}, D_{t}, \Pi_{t}} J_{t}
$$

subject to the cash flow, balance sheet, financing constraint and loan demand given by (3.7), (3.2), (3.11) and (2.11), respectively.

\subsubsection{Solution to the optimal bank valuation problem for expected losses}

In this subsection, we find a solution to Problem 4 when the capital constraint (3.6) holds as well as when it does not. In this regard, the main result can be stated and proved as follows.

Theorem 3.1 (solution to the optimal bank valuation problem (holding)). Suppose that $J$ and $V$ are given by (3.16) and (3.17), respectively, and $P\left(\mathrm{M}_{t}\right)=\alpha Q+\mathrm{E}[l] \Lambda_{t-1}$. When the capital constraint given by (3.6) holds (i.e., $l_{t}>0$ ), a solution to the optimal bank valuation problem yields an optimal bank loan supply and loan rate of the form

$$
\begin{gathered}
\Lambda_{t}^{*}=\frac{K_{t}}{\rho \omega\left(\mathrm{M}_{t}\right)}-\frac{\omega^{I} I_{t}+\omega^{S} S_{t}+12.5(m V a R+0)}{\omega\left(\mathrm{M}_{t}\right)} \\
r_{t}^{\Lambda *}=\frac{1}{l_{1}}\left(l_{0}+l_{2} \mathrm{M}_{t}+\sigma_{t}^{\Lambda}-\frac{K_{t}}{\rho \omega\left(\mathrm{M}_{t}\right)}+\frac{\omega^{I} I_{t}+\omega^{S} S_{t}+12.5(m V a R+0)}{\omega\left(\mathrm{M}_{t}\right)}\right),
\end{gathered}
$$

respectively. In this case, the corresponding optimal deposits, provisions for deposit withdrawals and profits are given by

$$
\begin{aligned}
D_{t}^{*}= & \bar{D}+\frac{\bar{D}(1-\gamma)}{r_{t}^{p}}\left[r_{t}^{\mathrm{T}}-\frac{\left(r_{t}^{D}+c^{D}\right)}{1-\gamma}\right]+\frac{K_{t}}{\rho \omega\left(\mathrm{M}_{t}\right)}-\frac{\omega^{I} I_{t}+\omega^{S} S_{t}+12.5(m V a R+0)}{\omega\left(\mathrm{M}_{t}\right)} \\
& +C_{t}+S_{t}+B_{t}-K_{t}-\mathrm{B}_{t}, \\
W_{t}^{*}=\bar{D} & +\frac{\bar{D}(1-\gamma)}{r_{t}^{p}}\left[r_{t}^{\mathrm{T}}-\frac{\left(r_{t}^{D}+c^{D}\right)}{1-\gamma}\right], \\
\Pi_{t}^{*}=( & \left.\frac{K_{t}}{\rho \omega\left(\mathrm{M}_{t}\right)}-\frac{\omega^{I} I_{t}+\omega^{S} S_{t}+12.5(m V a R+0)}{\omega\left(\mathrm{M}_{t}\right)}\right) \\
\times & \left\{\frac{1}{l_{1}}\left(l_{0}-\frac{K_{t}}{\rho \omega\left(\mathrm{M}_{t}\right)}+\frac{\omega^{I} I_{t}+\omega^{S} S_{t}+12.5(m V a R+0)}{\omega\left(\mathrm{M}_{t}\right)}+l_{2} \mathrm{M}_{t}+\sigma_{t}^{\Lambda}\right)\right. \\
& \left.-\left(c^{\Lambda}+\left(r_{t}^{D}+c^{D}+r_{t}^{\mathrm{T}} \gamma\right)+r^{d}\left(\mathrm{M}_{t}\right)\right)\right\}-\left(r_{t}^{D}+c^{D}+r_{t}^{\mathrm{T}} \gamma\right)\left(C_{t}+B_{t}+S_{t}-K_{t}-\mathrm{B}_{t}\right) \\
& +\left(\bar{D}+\frac{\bar{D}(1-\gamma)}{r_{t}^{p}}\left[r_{t}^{\mathrm{T}}-\frac{\left(r_{t}^{D}+c^{D}\right)}{1-\gamma}\right]\right)\left((1-\gamma) r_{t}^{\mathrm{T}}-\left(r_{t}^{D}+c^{D}\right)\right) \\
& -c^{w}\left(W_{t}\right)-P\left(\mathrm{M}_{t}\right)+r_{t}^{I} I_{t}+r_{t}^{C} C_{t}+r_{t}^{B} B_{t}+r_{t}^{S} S_{t},
\end{aligned}
$$

respectively. 
Proof. An immediate consequence of the prerequisite that the capital constraint (3.6) holds, is that loan supply is closely related to the capital adequacy constraint and is given by (3.18). Also, the dependence of changes in the loan rate on macroeconomic activity may be fixed as

$$
\frac{\partial r_{t}^{\Lambda^{*}}}{\partial \mathrm{M}_{t}}=\frac{l_{2}}{l_{1}}
$$

Equation (3.18) follows from (3.6) and the fact that the capital constraint holds. This also leads to equality in (3.6). In (3.19) we substituted the optimal value for $\Lambda_{t}$ into control law (2.11) to get the optimal default rate. We obtain the optimal $W_{t}$ using the following steps. Firstly, we rewrite (3.2) to make deposits the dependent variable so that

$$
D_{t}=W_{t}+\Lambda_{t}+C_{t}+B_{t}+S_{t}-K_{t}-B_{t}
$$

Next, we note that the first-order conditions (for verification of these conditions see Appendix A in the appendices ) are given by

$$
\begin{gathered}
\frac{\partial \Pi_{t}}{\partial r_{t}^{\Lambda}}\left[1+c_{t}^{\mathrm{dw}}-\mathbf{E}_{t}\left\{\int_{\underline{\Lambda}}^{\bar{\Lambda}} \delta_{t, 1} \frac{\partial V}{\partial K_{t+1}} d F\left(\sigma_{t+1}^{\Lambda}\right)\right\}\right]+l_{t} \rho l_{1} \omega\left(\mathrm{M}_{t}\right)=0 \\
\frac{\partial \Pi_{t}}{\partial D_{t}}\left[1+c_{t}^{\mathrm{dw}}-\mathrm{E}_{t}\left\{\int_{\underline{\Lambda}}^{\bar{\Lambda}} \delta_{t, 1} \frac{\partial V}{\partial K_{t+1}} d F\left(\sigma_{t+1}^{\Lambda}\right)\right\}\right]=0 \\
\rho\left[\omega\left(\mathrm{M}_{t}\right) \Lambda_{t}+\omega^{I} I_{t}+\omega^{S} S_{t}+12.5(m \mathrm{VaR}+0)\right] \leq K_{t} \\
-c_{t}^{\mathrm{dw}}+\mathrm{E}_{t}\left\{\int_{\underline{\Lambda}}^{\bar{\Lambda}} \delta_{t, 1} \frac{\partial V}{\partial K_{t+1}} d F\left(\sigma_{t+1}^{\Lambda}\right)\right\}=0 .
\end{gathered}
$$

Here $F(\cdot)$ is the cumulative distribution of the shock to the loans. Using (3.26) we can see that (3.24) becomes

$$
\frac{\partial \Pi_{t}}{\partial D_{t}}=0
$$

Looking at the form of $\Pi_{t}$ given in (3.7) and the equation

$$
c^{w}\left(W_{t}\right)=\frac{r_{t}^{p}}{2 \bar{D}}\left[\bar{D}-W_{t}\right]^{2}
$$


it follows that

$$
\begin{aligned}
\Pi_{t}= & \left(r_{t}^{\Lambda}-c^{\Lambda}-r^{d}\left(\mathrm{M}_{t}\right)\right) \Lambda_{t}+r_{t}^{\mathrm{T}} W_{t}+r_{t}^{I} I_{t}+r_{t}^{C} C_{t}+r_{t}^{B} B_{t}+r_{t}^{S} S_{t} \\
& -\left(r_{t}^{D}+c^{D}\right) D_{t}-\frac{r_{t}^{p}}{2 \bar{D}}\left[\bar{D}-W_{t}\right]^{2}-P\left(\mathrm{M}_{t}\right)-r_{t}^{\mathrm{T}} r D_{t} .
\end{aligned}
$$

Finding the partial derivatives of profit, $\Pi_{t}$, with respect to deposit, $D_{t}$, we have that

$$
\begin{aligned}
\frac{\partial \Pi_{t}}{\partial D_{t}} & =r_{t}^{\mathrm{T}}-\left(r_{t}^{D}+c^{D}\right)+\frac{r_{t}^{p}}{\bar{D}}\left(\bar{D}-W_{t}\right)-r_{t}^{\mathrm{T}} \gamma \\
& =(1-r) r_{t}^{\mathrm{T}}-\left(r_{t}^{D}+c^{D}\right)+\frac{r_{t}^{p}}{\bar{D}}\left(\bar{D}-W_{t}\right)=0 .
\end{aligned}
$$

This would then give us the optimal value for $D_{t}$. Using (3.2) and all the optimal values calculated to date, we can find optimal deposits, and the same goes for optimal profits.

Remark 3.2 (solution to the optimal bank valuation problem). Theorem 3.1 addresses a very important issue in bank operations that is related to the optimal supply of loans under regulatory constraint. In order for the bank to fulfill its primary role as a credit provider, (3.18) should satisfy the condition

$$
\frac{K_{t}}{\rho \omega\left(\mathrm{M}_{t}\right)}>\frac{\omega^{I} I_{t}+\omega^{S} S_{t}+12.5(m \mathrm{VaR}+0)}{\omega\left(\mathrm{M}_{t}\right)} .
$$

In other words, the optimal loan supply, $\Lambda^{*}$, should have a positive value. A similar comment can be made about the optimal loan rate, $r^{\Lambda *}$ in (3.19). If we substitute (3.26) in Subsection 3.4 into the optimal decisions for the loan rate and deposits represented by (3.23) and (3.24), respectively, we can obtain a time-independent solution for the optimal bank valuation problem. This leads to a significant reduction in the technical difficulty of the procedure.

In the case where the constraint (3.6) does not hold, the following corollary follows directly.

Corollary 3.3 (solution to the optimal bank valuation problem (not holding)). Suppose that $J$ and $V$ are given by (3.16) and (3.17), respectively, and $P\left(\mathrm{M}_{t}\right)=\alpha \rho+\mathrm{E}[l] \Lambda_{t-1}$. When the capital constraint (3.6) does not hold (i.e., $l_{t}=0$ ), a solution to the optimal bank valuation problem stated in Problem 4 yields the optimal bank loan supply and loan rate

$$
\begin{aligned}
& \Lambda_{t}^{n *}=\frac{1}{2}\left(l_{0}+l_{2} \mathrm{M}_{t}+\sigma_{t}^{\Lambda}\right)-\frac{l_{1}}{2}\left(c^{\Lambda}+r^{d}\left(\mathrm{M}_{t}\right)+\left(r_{t}^{D}+c^{D}\right)+r_{t}^{\mathrm{T}} \gamma\right) \\
& r_{t}^{\Lambda^{n *}}=\frac{1}{2 l_{1}}\left(l_{0}+l_{2} \mathrm{M}_{t}+\sigma_{t}^{\Lambda}\right)+\frac{1}{2}\left(c^{\Lambda}+r^{d}\left(\mathrm{M}_{t}\right)+\left(r_{t}^{D}+c^{D}\right)+r_{t}^{\mathrm{T}} \gamma\right)
\end{aligned}
$$


respectively. In this case, the corresponding $W_{t}$, deposits and profits are given by

$$
\begin{aligned}
W_{t}^{n *}= & \bar{D}+\frac{\bar{D}(1-\gamma)}{r_{t}^{p}}\left(r_{t}^{\mathrm{T}}-\frac{\left(r_{t}^{D}+c^{D}\right)}{1-\gamma}\right), \\
D_{t}^{n *}= & \bar{D}+\frac{\bar{D}(1-\gamma)}{r_{t}^{p}}\left(r_{t}^{\mathrm{T}}-\frac{\left(r_{t}^{D}+c^{D}\right)}{1-\gamma}\right)+\Lambda_{t}^{n *}+C_{t}+B_{t}+S_{t}-K_{t}-\mathrm{B}_{t}, \\
\Pi_{t}^{n *}= & \frac{1}{2}\left(l_{0}+l_{2} \mathrm{M}_{t}+\sigma_{t}^{\Lambda}\right)-\frac{l_{1}}{2}\left(c^{\Lambda}+\left(r_{t}^{D}+c^{D}\right)+r^{d}\left(\mathrm{M}_{t}\right)+r_{t}^{\mathrm{T}}(\gamma)\right) \\
& \times\left\{\frac{1}{2 l_{1}}\left(l_{0}+l_{2} \mathrm{M}_{t}+\sigma_{t}^{\Lambda}\right)-\frac{1}{2}\left(c^{\Lambda}+\left(r_{t}^{D}+c^{D}\right)+r^{d}\left(\mathrm{M}_{t}\right)+r_{t}^{\mathrm{T}} \gamma\right)\right\} \\
& -\left(r_{t}^{D}+c^{D}+r_{t}^{\mathrm{T}} \gamma\right)\left(C_{t}+B_{t}+S_{t}-K_{t}-\mathrm{B}_{t}\right)+\left(\bar{D}+\frac{\bar{D}(1-\gamma)}{r_{t}^{p}}\left[r_{t}^{\mathrm{T}}-\frac{\left(r_{t}^{D}+c^{D}\right)}{1-\gamma}\right]\right) \\
& \times\left((1-\gamma) r_{t}^{\mathrm{T}}-\left(r_{t}^{D}+c^{D}\right)\right)-c^{w}\left(W_{t}\right)-P\left(\mathrm{M}_{t}\right)+r_{t}^{I} I_{t}+r_{t}^{C} C_{t}+r_{t}^{B} B_{t}+r_{t}^{S} S_{t},
\end{aligned}
$$

respectively.

Proof. For the situation where capital constraint (3.6) does not hold (i.e., $l_{t}=0$ ), using equation (3.26) and the fact that $l_{t}=0$, we can see that (3.23) becomes

$$
\frac{\partial \Pi_{t}}{\partial r_{t}^{\Lambda}}=0
$$

As in the proof of Theorem 3.1, looking at the form of $\Pi_{t}$ given in (3.7) and (3.28), we have equation (3.29). Therefore

$$
\frac{\partial \Pi_{t}}{\partial r_{t}^{\Lambda}}=\Lambda_{t}-l_{1}\left(r_{t}^{\Lambda}-c^{\Lambda}-r^{d}\left(\mathrm{M}_{t}\right)\right)+l_{1} r_{t}^{\mathrm{T}}+\frac{r_{t}^{p}}{\bar{D}}\left(\bar{D}-W_{t}\right) l_{1}=0
$$

By substitute (3.30) into (3.35) and using (2.11) would give us optimal loans and loan rate given by (3.31) and (3.32), respectively. Furthermore we can find the optimal deposit, deposit withdrawals and profits.

\section{Historical evidence and examples}

In this section, we firstly provide evidence to support the fact that the output gap (proxy for the business cycle) and the provisions for loan losses-to-total assets ratio are negatively correlated. In essence this means that (2.17) holds and provisions for loan losses are procyclical. Secondly, in Subsection 4.2, we investigate the correlation between output gap and provisions in relation to profitability. Also, the historical data provides support for our modeling choices for provisions and profitability in Sections 2 and 3.

Throughout this section, we rely on historical data from member countries of the Organization for Economic Corporation and Development (OECD) as supplied on the 
website [50]. The specific countries or regions for which data was accessed are Australia, Finland, Italy, Japan, Norway, Spain, Sweden, the United Kingdom and the United States.

\subsection{Procyclicality of provisions for loan losses}

In this subsection, we look at empirical evidence that provisions for loan losses is procyclical. In other words, we would like to verify that (2.17) holds.

\subsubsection{Provisioning for Australia, Norway, Spain and Sweden}

This subsubsection provides empirical evidence that provisions for loan losses for the period 1986 to 2000 were procyclical in Australia, Norway, Spain and Sweden (see Figures 1 and 2).

\subsubsection{Provisioning for Finland, Italy, Japan and United Kingdom}

This subsubsection provides empirical evidence that provisions for loan losses in Finland, Italy, Japan and United Kingdom were procyclical for the period 1986 to 2000 (see Figures 3 and 4).

\subsubsection{Provisioning for the United States}

This subsubsection provides empirical evidence that in the U.S. provisions for loan losses were procyclical for the period 1986 to 2000 (see Figure 5).

\subsubsection{Discussion of provisioning for the 9 OECD countries}

In this sububsection, we provide a brief discussion of some of the outstanding features of the data for provisioning for loan losses provided in Subsubsections 4.1.1, 4.1.2 and 4.1.3.

The data for Australia from Figure 1 shows that provisions failed to increase substantially in the late 1980 's, when credit and asset prices were growing rapidly and the financial imbalances were developing. Moreover, the peak in provisions did not occur until at least one year after the economy had clearly slowed down.

The data for Norway from Figure 1 exhibits a similar behavior as the data for Finland from Figure 3 and the data for Spain from Figure 2. In these cases, provisions failed to increase substantially in the late 1980 's, when credit and asset prices were growing rapidly and the financial imbalances were developing. In each of these figures the peak for provisions did not occur until the recession. However, one of the differences between these figures is the amount by which provisions increased when the economy had clearly slowed down.

In the data for Finland from Figure 3 we see a similar situation as in the data for Italy from Figure 3 where provisions failed to overlap the output gap during the recession. Again this can be link with Japanese banking problems. Although in countries like the United States (see Figure 5) and Australia and Norway (see Figure 1), the provisions overlapped the output gap during the recessions, the situation in Italy (see Figure 3) is total different. It seems that even after the banking problems that Japan experienced had been resolved, in Italy the situation changed slightly.

From the data for Japan from Figure 4, we can conclude that the level of provisioning only increased substantially during the second half of the 1990's, long after the problems in the Japanese banking system had been widely recognized. 


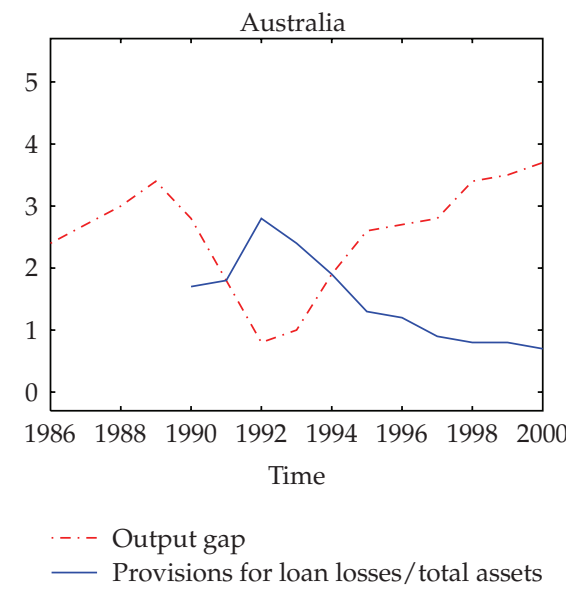

(a)

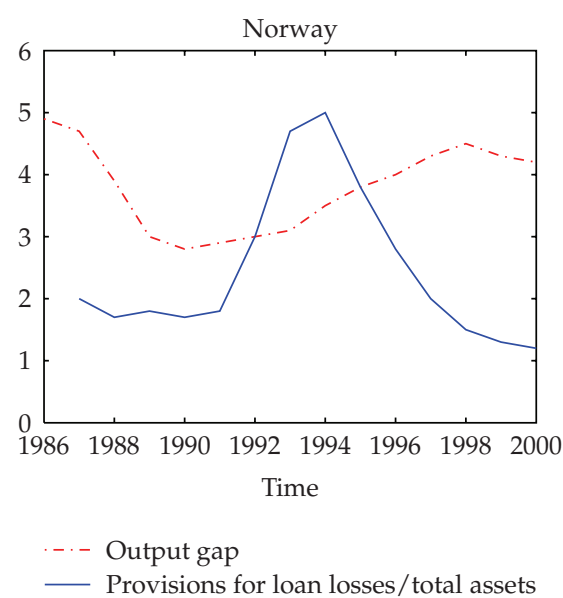

(b)

Figure 1: Output gap versus provisions for loan losses-to-total assets ratio for Australia and Norway (19862000).

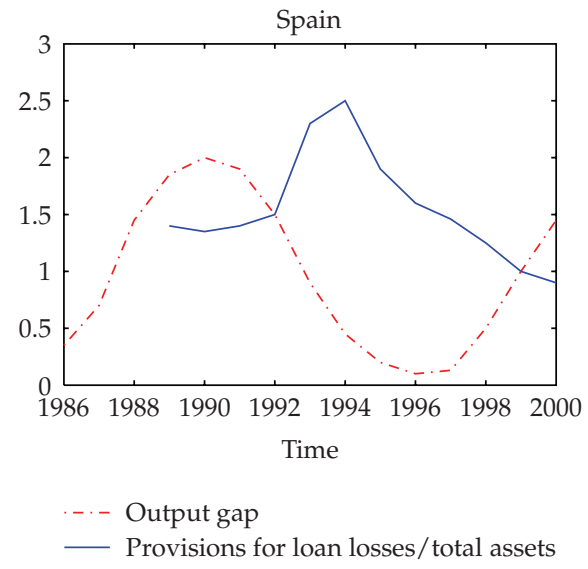

(a)

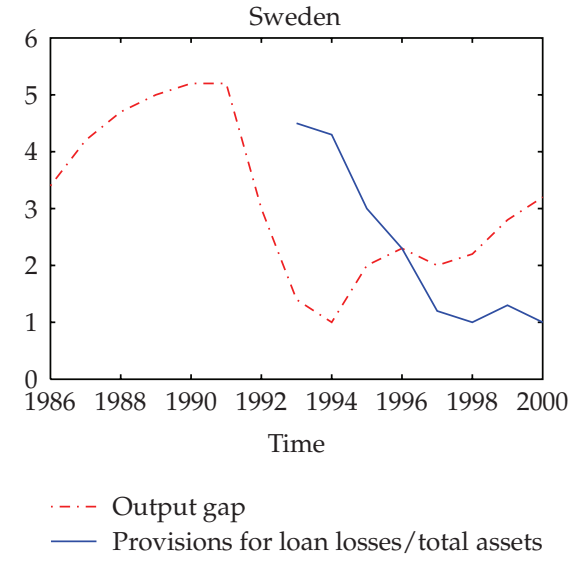

(b)

Figure 2: Output gap versus provisions for loan losses-to-total assets ratio for Spain and Sweden (19862000).

The (low) positive correlation between provisions and the business cycle in the United States (see Figure 5) appears to be driven by the surge in provisions in the second half of the 1980 's. This phenomenon seems to reflect the delayed cleaning of the balance sheets following the developing countries' debt crisis of the early 1980's.

\subsection{Correlations between profitability and provisions for loan losses}

As has been suggested in Subsection 4.1, bank provisions are strongly procyclical and are negatively correlated with the business cycle. For instance, Figure 5 shows that provisions typically do not increase until after economic growth has slowed down considerably and often not until the economy is in complete recession. In the main, the behavior of provisions 


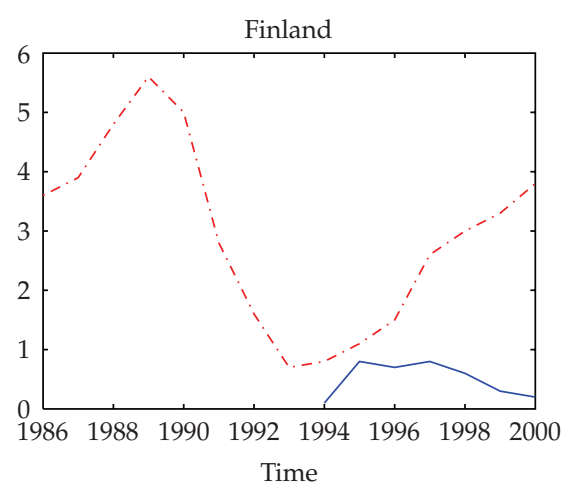

-..- Output gap

— Provisions for loan losses/total assets

(a)

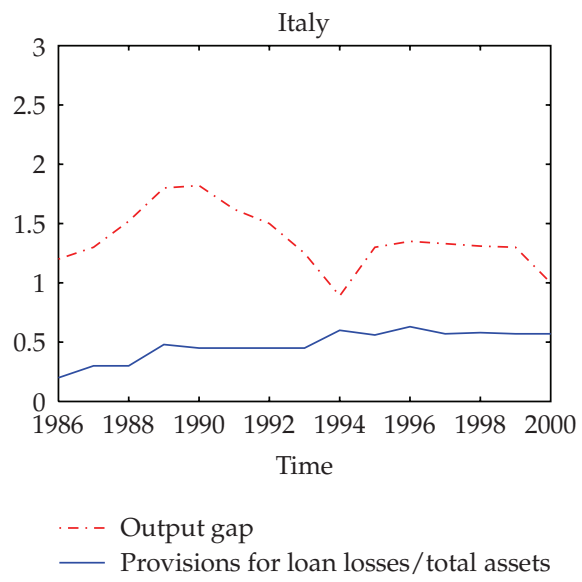

(b)

Figure 3: Output gap versus provisions for loan losses-to-total assets ratio for Finland and Italy (19862000).

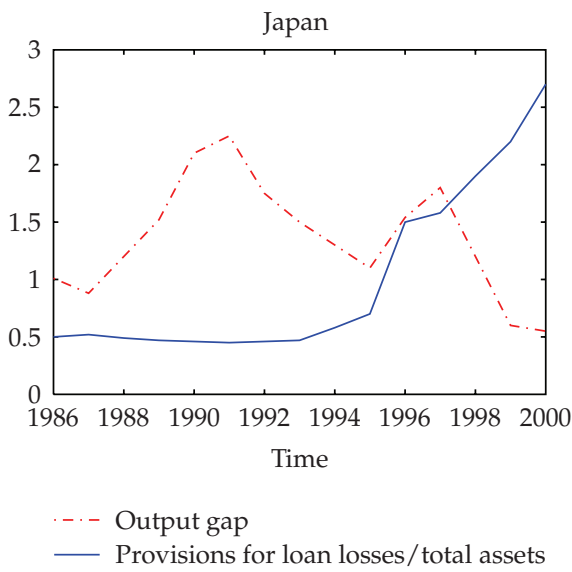

(a)

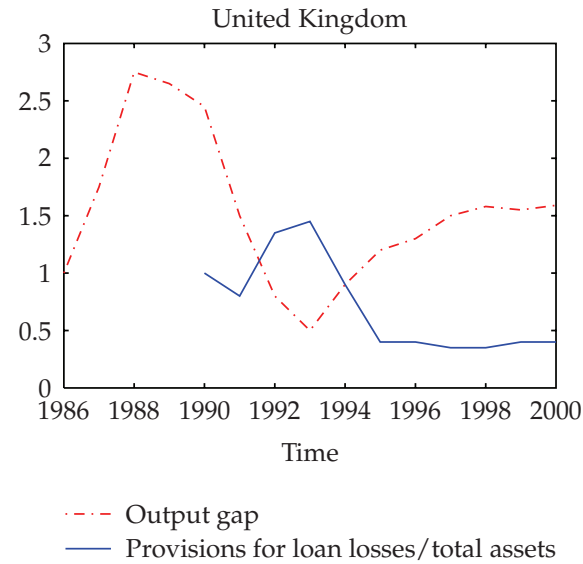

(b)

Figure 4: Output gap versus provisions for loan losses-to-total assets ratio for Japan and United Kingdom (1986-2000).

translates into a clear procyclical pattern in bank profitability, which further encourages procyclical lending practices. As is shown in Table 2, this pattern appears to be strongest in those countries that experienced banking system problems in the 1990's.

In the main, the behavior of provisions translates into a procyclical pattern in bank profitability, which further encourages procyclical lending practices. Our claim is thus that profit and provisions are negatively correlated. However, from Table 2, we also conclude that the profitability of German banks is not procyclical. This may be due to their ability to smooth profits through hidden reserves. The procyclical nature of bank profits has arguably also contributed to the bank equity prices being positively correlated with the business cycle, although the correlation is typically weaker than that for profitability, reflecting the forwardlooking nature of the equity market. 
Table 2: Correlations between provisions and profitability.

\begin{tabular}{lcc}
\hline Countries & Provisions & Profitability \\
\hline Australia & $-0,88$ & 0,71 \\
Finland & - & 0,81 \\
Germany & $-0,21$ & $-0,42$ \\
Italy & $-0,21$ & 0,25 \\
Japan & $-0,43$ & 0,22 \\
Norway & $-0,35$ & 0,54 \\
South Africa & $-0,85$ & 0,74 \\
Spain & $-0,41$ & 0,84 \\
Sweden & $-0,83$ & 0,60 \\
United Kingdom & $-0,38$ & 0,12 \\
United States & 0,14 & 0,24 \\
\hline
\end{tabular}

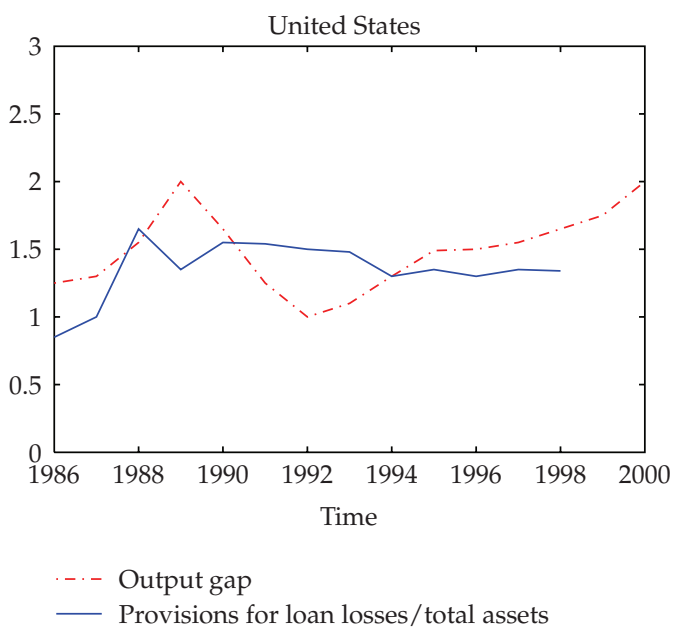

Figure 5: Output gap versus provisions for loan losses-to-total assets ratio for the United States (19862000).

\section{Bank valuation and its connections with the subprime mortgage crisis and Basel II}

In this section, we consider connections between the discrete-time stochastic models derived in the preceding discussions and the SMC as well as the Basel II Capital Accord.

\subsection{Bank valuation and the subprime mortgage crisis}

The SMC is an ongoing crisis characterized by shrinking liquidity in global credit markets and banking systems. A downturn in the U.S. housing market, risky practices by lenders and borrowers and excessive individual and corporate debt levels have affected the world economy adversely on a number of levels. The SMC has exposed pervasive weaknesses in the global financial system and regulatory framework. The connections between this crisis 
and our banking models are mainly forged via the bank's

(i) risk premium, $Q$, from (2.5) in Subsection 2.2.1 (see HM1 and HM2 in Figure 6);

(ii) required capital sensitivity to changes in the amount of loans extended as given by (2.6) in Subsection 2.2.1 (see FM2 in Figure 6);

(iii) base rate, $r$, from (2.7) in Subsection 2.2.1 decided upon by Central Banks as well as interbank loan rates (see HM1, HM3, FM4 and GIR1 in Figure 6);

(iv) own loan rate, $r^{\Lambda}$, from (2.7) and (2.7) and (3.32) in Subsections 2.2.1 and 3.4.2, respectively (see HM1, HM3, FM4 and GIR1 in Figure 6);

(v) loan demand represented by (2.11) in Subsection 2.2.1 (see HM3, FM4, GIR1 and GIR5 in Figure 6);

(vi) loan losses and default rate given by (2.13) in Subsection 2.2.2 (see HM4, FM1, FM3, GIR3 and GIR5 in Figure 6);

(vii) loan loss provisions from (2.16) and (2.17) in Subsection 2.2.2 and illustrated in Subsection 4.1 (see HM4, FM1, FM3, GIR3 and GIR5 in Figure 6);

(viii) choice between raising deposits and interbank borrowing (including borrowing from the Central Bank) as reflected by (2.21) in Subsection 2.3.3 (see GIR1 in Figure 6);

(ix) liquidity as described by Remark 2.3 (see FM4 in Figure 6);

(x) profit, $\Pi$, given by (3.7) in Subsection 3.2.1 and illustrated in Subsection 4.2 (see HM2, HM4, FM1, FM3, GIR1 and GIR5 in Figure 6);

(xi) bank valuation performance criterion, $J$, given by (3.16) in Subsection 3.4 .1 (see HM4, HM6, FM1, FM2 and FM3 in Figure 6).

In this subsection, we provide a diagrammatic overview of and sketch a background to the SMC. Furthermore, we briefly consider the connections between our banking models and the SMC.

\subsubsection{Diagrammatic overview of the subprime mortgage crisis}

A diagrammatic overview of the SMC (see, for instance, [51]) may be represented as in Figure 6.

\subsubsection{Background to the subprime mortgage crisis}

Most of the information contained in this subsection was sourced from [51]. The SMC was initiated by the deflation of the United States housing bubble (see, for instance, $[52,53]$ ) and high default rates on subprime and adjustable rate mortgages (ARM). Loan incentives, such as easy initial terms and low loan rates, in combination with escalating housing prices encouraged borrowers to assume difficult mortgages on the belief they would be able to quickly refinance at more favorable terms (see HM1 in Figure 6). Great concern was also expressed about the rapid growth in business loans at commercial banks with excessively easy credit standards. Some analysts claim that competition for lenders had greatly increased, causing banks to reduce loan rates and ease credit standards in order to issue new credit. Others are of the opinion that as the economic expansion continued and past loan losses 


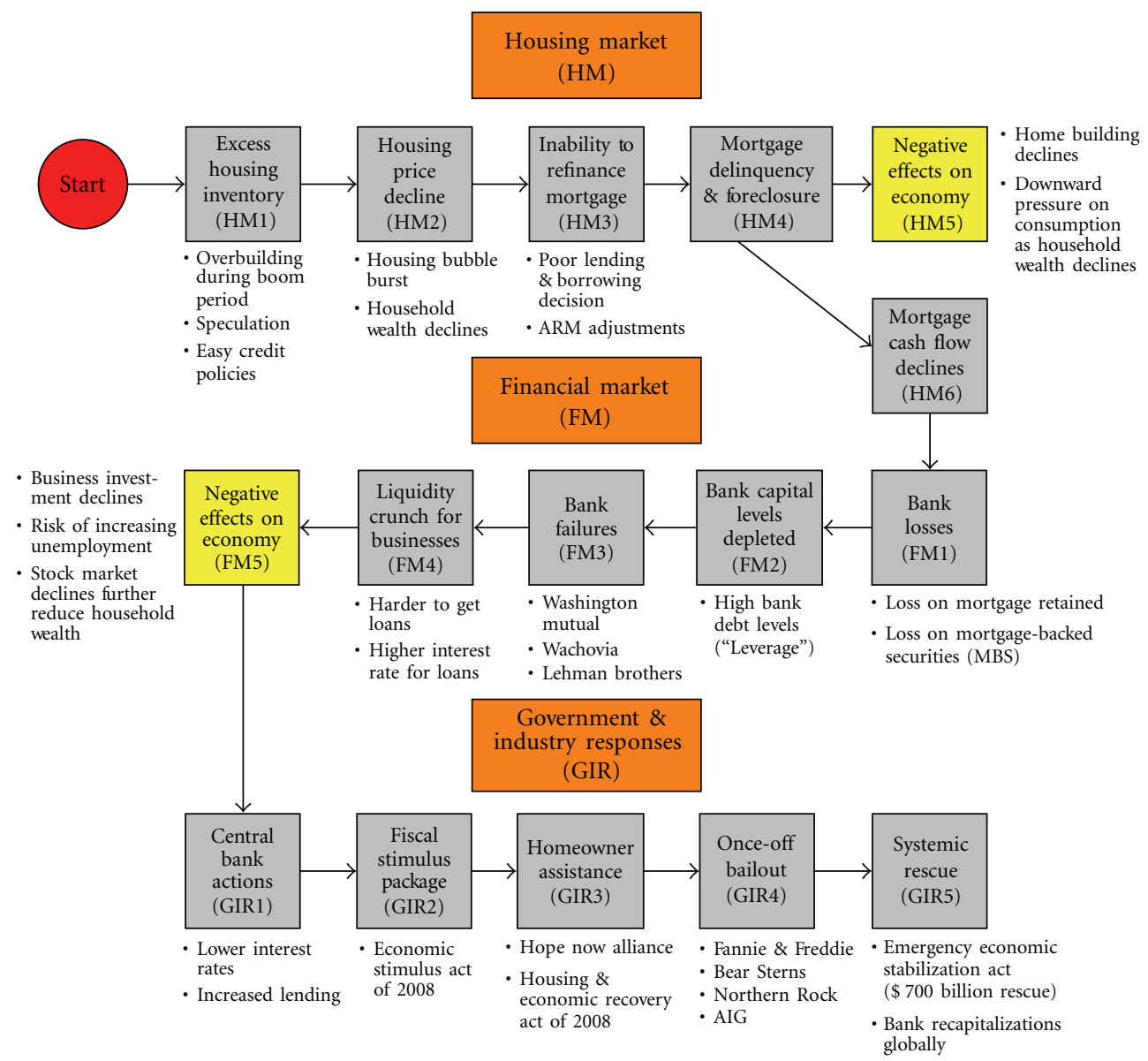

Figure 6: Diagrammatic overview of the subprime mortgage crisis (compare [51]).

were forgotten, banks exhibited a greater propensity for risk. However, once U.S. housing prices started to fall moderately in 2006-2007, refinancing became more difficult (see HM2 and HM3 in Figure 6). Defaults and foreclosure activity increased dramatically, as easy initial terms expired, home prices failed to go up as anticipated, and ARM interest rates reset higher. Foreclosures accelerated in the U.S. in late 2006 and triggered a global financial crisis through 2007 and 2008. During 2007, nearly 1.3 million U.S. housing properties were subjected to foreclosure activity; up 79\% from 2006 (see [54] for more details; also HM4 in Figure 6). The mortgage lenders that retained credit risk were the first to be affected, as borrowers became unable or unwilling to make payments (see HM5 and HM6 in Figure 6).

Major banks and other financial institutions globally had reported losses of approximately $\$ 435$ billion from SMC-related activities by Thursday, 17 July 2008 (see [55, 56]; also FM1 in Figure 6). By using securitization strategies, many mortgage lenders passed the rights to the mortgage payments and related credit risk to third-party investors via mortgage-backed securities (MBSs) and collateralized debt obligations (CDOs). Corporate, individual and institutional investors holding MBS or CDO suffered significant losses, as the underlying mortgage asset value decreased. Stock markets in many countries declined significantly (see FM2 in Figure 6). The broader international financial sector first began to 
experience the fallout from the SMC in February 2007 with the $\$ 10.5$ billion writedown of HSBC, which was the first major CDO or Mortgage Bankers Association (MBA) related loss to be reported. During 2007, at least 100 mortgage companies had either failed, suspended operations or been sold. Top management did not escape without blemish, as the CEOs of Merrill Lynch and Citigroup were forced to resign within a week of each other. Subsequently, merger deals were struck by many institutions. In addition, Northern Rock and Bear Stearns required emergency assistance from central banks. IndyMac was shut down by the FDIC on Sunday, 11 July 2008. Moreover, on Sunday, 14 September 2008, after performing banking duties for more than 150 years, Lehman Brothers filed for bankruptcy as a consequence of losses stemming from the SMC (see FM3 in Figure 6). Subsequent to this many U.S. and other banks throughout the world also failed. The widespread dispersion of credit risk and the unclear effect on financial institutions caused reduced lending activity and increased spreads on higher interest rates. Similarly, the ability of corporations to obtain funds through the issuance of commercial paper was affected. This aspect of the crisis is consistent with a credit crunch. There are a number of reasons why banks may suddenly make obtaining a loan more difficult or increase the costs of obtaining a loan. This may be due to an anticipated decline in the value of the collateral used by the banks when issuing loans; an increased perception of risk regarding the solvency of other banks within the banking system; a change in monetary conditions (e.g., where the central bank suddenly and unexpectedly raises interest rates or capital requirements); the central government imposing direct credit controls and instructing the banks not to engage in further lending activity. The subprime crisis has adversely affected several inputs in the economy, resulting in downward pressure on economic growth. Fewer and more expensive loans tend to result in decreased business investment and consumer spending (see FM4 and FM5 in Figure 6).

Liquidity concerns drove central banks around the world to take action to provide funds to member banks to encourage lending to worthy borrowers and to restore faith in the commercial paper markets (see GIR1 in Figure 6). With interest rates on a large number of subprime and other ARM due to adjust upward during the 2008 period, U.S. legislators, the U.S. Treasury Department, and financial institutions took action. A systematic program to limit or defer interest rate adjustments was implemented to reduce the effect. In addition, lenders and borrowers facing defaults have been encouraged to cooperate to enable borrowers to stay in their homes. Banks have sought and received over $\$ 250$ billion in additional funds from investors to offset losses (see [57] for more information). The risks to the broader economy created by the financial market crisis and housing market downturn were primary factors in several decisions by the U.S. Federal Reserve to cut interest rates and the Economic Stimulus Package (ESP) passed by Congress and signed by President Bush on Wednesday, 13 February 2008 (see, for instance, [58-60]; also GIR2 in Figure 6). Bush also announced a plan voluntarily and temporarily to freeze the mortgages of a limited number of mortgage debtors holding ARMs. A refinancing facility called FHA-Secure was also created. This action is part of an ongoing collaborative effort between the U.S. government and private industry to help some subprime borrowers called the Hope Now Alliance (see GIR3 in Figure 6). The U.S. government also bailed-out key financial institutions, assuming significant additional financial commitments (see GIR4 in Figure 6). Following a series of adhoc market interventions to bailout particular firms, a $\$ 700$ billion systemic rescue plan was accepted by the U.S. House of Representatives on Friday, 3 October 2008. These actions are designed to stimulate economic growth and inspire confidence in the financial markets (see GIR5 in Figure 6). By November 2008, banks in Europe, Asia, Australia and South America had followed the example of the U.S. government by putting rescue plans in place. 


\subsubsection{Connections between our models and the subprime mortgage crisis}

The connections between our banking models and the SMC are complicated. However, a first step towards understanding this relationship entails identifying the problematic loan subportfolios. In this regard, it is possible to decompose the (total) loans, $\Lambda$, discussed above as

$$
\Lambda=\sum_{i=1}^{m} \Lambda_{i}
$$

where $m$ is the number of loan subportfolios with $i$ being the index of each loan subportfolio so that $i=1,2, \ldots, m$. We note that the Basel II IRB approach to credit risk (see [2]) dictates that $m \leq$ 15. In particular, this approach identifies 15 credit risk exposure types (loan subportfolios) that may be listed as

$$
\begin{aligned}
& i=1 \text { : Project finance }(\mathrm{PF}) \text {; } \\
& i=2 \text { : Object finance }(\mathrm{OF}) \text {; } \\
& i=3 \text { : Commodities finance }(\mathrm{CF}) \text {; } \\
& i=4 \text { : Income producing real estate (IPRE); } \\
& i=5 \text { : Specialized lending high volatility commercial real estate (SLHVCRE) } \\
& i=6 \text { : Specialized lending not including high volatility commercial real estate } \\
& \text { (SLNIHVCRE) } \\
& i=7 \text { : Bank exposure (BE); } \\
& i=8 \text { : Sovereign exposure (SE); } \\
& i=9 \text { : Retail residential mortgage (RRM); } \\
& i=10 \text { : Home equity line of credit (HELOC); } \\
& i=11 \text { : Other retail exposure (ORE); } \\
& i=12 \text { : Qualifying revolving retail exposure (QRRE); } \\
& i=13 \text { : Small to medium size enterprises with corporate treatment (SMECT) } \\
& i=14 \text { : Small to medium size enterprises with retail treatment (SMERT) } \\
& i=15 \text { : Equity exposure not held in the trading book (EENHTB) }
\end{aligned}
$$

with $i=1-6$ and $i=9-12$ constituting corporate and retail exposures, respectively. As a result of the SMC, market trade in almost all of these loan subportfolios became sluggish. In particular, a problematic loan subportfolio corresponds to $i=4$ which encompasses income producing real estate. Furthermore, in commercial real estate (i.e., $i=5$ and $i=6$ ) there is a slowing due to the tightening credit and slowing growth, the former a direct result of the SMC. Although capital remains available for residential loans, the credit crunch is pronounced in commercial lending. Moreover, $i=7$ which corresponds to interbank lending had been identified as a problematic subportfolio. This is because banks were not lending to each other during the early stages of the crisis (see FM4 in Figure 6).

The risk premium, $Q$, from (2.5) has had a part to play in the SMC (see HM1 in Figure 6). This premium is part of the expression for the bank's own loan rate, $r^{\Lambda}$, and its size is an indication of perceived credit risk. A study by the U.S. Federal Reserve indicated that the 
average difference in mortgage interest rates between subprime ("subprime markup") and prime mortgages declined from $\rho=2.8$ percentage points ( 280 basis points) in 2001, to $\rho=1.3$ percentage points in 2007. In other words, the risk premium required by lenders to offer a subprime loan declined dramatically during the aforementioned period. This occurred even though subprime borrower and loan quality declined overall during the 2001-2006 period. In fact, this state of affairs should have had the opposite effect. However, it is clear that such conditions are consistent with classic boom and recession credit cycles (see [37]).

The sensitivity of the required capital to changes in the amount of loans extended from (2.6) is an important issue in the SMC. Bank capital levels were depleted with banks experiencing high debt levels (see FM2 in Figure 6). As a consequence, for many banks (2.6) begun to take on negative values during the SMC.

The Central Bank base rate, $r$, from (2.7) in Subsection 2.2.1 has also had a role to play in trying to alleviate global economic pressures during the SMC. For instance, on Wednesday, 8 October 2008, central banks in the U.S. (U.S. Federal Reserve), England, China, Canada, Sweden, Switzerland and the European Central Bank cut rates in a coordinated effort to assist the world economy. This rate will be lowered when it is necessary to stimulate growth and provide liquidity.

Despite the discussion above, the most significant relationships between our models and the SMC are established via the bank's own loan rate, $r^{\Lambda}$, given by (2.7) (see also (3.19) and (3.32) as well as HM1, HM3, FM4 and GIR1 in Figure 6). As we have noted in (2.7), this loan rate may be expressed as

$$
r_{t}^{\Lambda}=\rho+\left(1+r_{t}\right) \frac{N}{\eta}+c^{\mathrm{rw}}+c^{E} \frac{\partial K}{\partial \Lambda}+\mathbf{E}[l]
$$

In general terms, $r^{\Lambda}$ can be written as a function of credit risk, market structure (power), marginal cost of debt, marginal cost of equity and the sensitivity of capital to loans extended. The representation of the bank's interest setting intimates that banks will experience positive returns in good times when the actual rate of default, $r^{d}$, is lower than the provisioning for expected losses, $\alpha \rho+\mathrm{E}[l]$, and may not be able to cover their expected losses when $r^{d}>$ $\alpha \rho+\mathbf{E}[l]$ (see equation (2.13) for loan losses and default rate). In the latter case, bank capital may be needed to cover these excess (and unexpected) losses. If this capital is not enough then the bank will face insolvency. During the latter half of 2008, we have seen a decline in such capital.

A combination of factors resulting from the SMC have led to problems in the commercial real estate market as regards loan demand (see (2.11); also HM3, FM4, GIR1 and GIR5 in Figure 6). According to the National Association of Realtors (NAR) there is a slowing in commercial real estate due to the tightening credit and slowing growth, the former a direct result of the SMC. Although capital remains available for residential loans, the credit crunch is pronounced in commercial lending. Patricia Nooney, chairperson of the Realtors Commercial Alliance Committee (RCAC), portrayed the decline as unusual since

"transactions are being curtailed not for lack of demand, but for serious challenges in obtaining financing." (see [61] for more information).

Next, we discuss loan losses and default rate given by (2.13) in Subsection 2.2.2 (see HM4, FM1, FM3, GIR3 and GIR5 in Figure 6). An acceleration in loan growth, as was experienced prior to the SMC, eventually leads to a surge in loan losses (see, for instance, 
(2.13) for loan losses and default rate) resulting in reduced bank profits (see equation (3.7) for bank profit) and precipitating a new round of bank failures. As experience during the mortgage crisis has shown, such a slump in banking could not only threaten the deposit insurance fund but also slow the economy by entrenching credit crunches. The view that faster loan growth leads to higher loan losses should not be taken lightly; nor should it be accepted without question. If loan growth increases because banks become more willing to lend, credit standards should fall and loan losses should eventually rise. For many distressed banks suffering because of the SMC, increased loan loss provisions from (2.16) and (2.17) translate to a decrease in earnings.

Usually, when capital is needed, banks have to choose between raising and holding deposits and borrowing from the Central Bank as reflected by (2.21) in Subsection 2.3.3.

Contracted liquidity in the global credit markets and banking system (as described by Remark 2.3; see also FM4 in Figure 6) is an ongoing economic problem. These liquidity concerns drove central banks around the world to take action to provide funds to member banks to encourage lending to worthy borrowers and to restore faith in the commercial paper markets (see GIR1 in Figure 6).

We recall that the bank's profits are given by (3.7) in the form

$$
\begin{aligned}
\Pi_{t}= & \left(r_{t}^{\Lambda}-c_{t}^{\Lambda}-r^{d}\left(\mathrm{M}_{t}\right)\right) \Lambda_{t}+r_{t}^{\mathrm{T}} W_{t}+r_{t}^{I} I_{t}+r_{t}^{\mathrm{C}} C_{t}+r_{t}^{B} B_{t}+r_{t}^{S} S_{t} \\
& -\left(r_{t}^{D}+c_{t}^{D}\right) D_{t}-c^{w}\left(W_{t}\right)-P\left(\mathrm{M}_{t}\right)-r_{t}^{\mathrm{T}} \gamma D_{t} .
\end{aligned}
$$

It is important to note that this expression represents the bank's profits from unsecuritized loans. However, in the SMC, the attention has been on borrowing under securitization strategies (see Figure 9 in Subsection C.1). In principle, we can provide an analogue of (3.7) in a securitization context by introducing additional variables. In this regard, suppose that $r^{r}$ is the average residual rate in securitized transactions, $p^{\text {rc }}$ the average expected fraction of loan losses on securitized debt, $c^{\text {li }}$ the marginal cost of mortgage loan insurance under securitization, $c^{\mathrm{mw}}$ the marginal cost to monitor a loan that was securitized, $c^{\mathrm{tw}}$ the marginal transaction costs to securitize a loan amortized over a loan term, $p^{w}$ the fraction of the loan amount securitized and $\tilde{p}^{w}$ the fraction of the mortgage loan principal, $\Lambda_{0}$, realized as a new loan in securitization. Then the bank's profits under securitization, $\Pi_{t}^{w}$, may be presented in the form

$$
\begin{aligned}
\Pi_{t}^{w}= & \left(r_{t}^{r}-p_{t}^{\mathrm{rc}}-c_{t}^{\mathrm{li}}-c_{t}^{\mathrm{mw}}-c_{t}^{\mathrm{tw}}\right) p_{t}^{w} \tilde{p}_{t}^{w} \Lambda_{t}+\left(r_{t}^{\Lambda}-c_{t}^{\mathrm{lc}}-c_{t}^{\mathrm{tw}}\right) p_{t}^{w}\left(1-\tilde{p}_{t}^{w}\right) \Lambda_{t} \\
& +\left(1-p_{t}^{w}\right)\left[\left(r_{t}^{\Lambda}-c_{t}^{\Lambda}-r^{d}\left(\mathrm{M}_{t}\right)\right) \Lambda_{t}+r_{t}^{\mathrm{T}} W_{t}+r_{t}^{I} I_{t}+r_{t}^{C} C_{t}+r_{t}^{B} B_{t}+r_{t}^{S} S_{t}\right. \\
& \left.-\left(r_{t}^{D}+c_{t}^{D}\right) D_{t}-c^{w}\left(W_{t}\right)-P\left(\mathrm{M}_{t}\right)-r_{t}^{\mathrm{T}} \gamma D_{t}\right]-V_{t}^{a}-\mathrm{E}_{t}-\mathrm{F}_{t} .
\end{aligned}
$$

Here we note that, in terms of the organization of the special purposes vehicle (SPV), there are different states that can be associated with the different possible corporate forms of the SPV. The SPV can be an $\operatorname{LLC}\left(E^{1}\right), \operatorname{LLP}\left(E^{2}\right), C$-corporation $\left(E^{3}\right)$ or a trust $\left(E^{4}\right)$. Each of these SPVs has its own unique tax benefits and problems as well as degree of asset protection and limited liability under legal prescripts. Furthermore, we denote the optimal state during the lifetime of the SPV by $E^{*}$, with deviations from $E^{*}$ being given by $\left|E^{*}-E_{t}^{i}\right|$, where $i=$ $1,2,3, \ldots, 4$. These deviations measure the loss and opportunity costs arising from the use 
of suboptimal corporate structures as SPVs. Usually, such loss manifests as elevated legal fees, increased losses due to low limited-liability and/or the value of additional time spent in dispute resolution. In this case, the formula for $\mathrm{E}$ in (5.4) may be given by

$$
E_{t}=\max \left\{\left|E^{*}-E_{t}^{1}\right|,\left|E^{*}-E_{t}^{2}\right|,\left|E^{*}-E_{t}^{3}\right|,\left|E^{*}-E_{t}^{4}\right|, 0\right\} .
$$

Furthermore, in the securitization context of (5.4), we assume that financing can take the form of $\mathrm{F}^{f}$, where the transaction is an assignment and $\mathrm{F}^{s}$, where the transaction is a true sale. In the former case, the SPV is not subsidized by the sponsor. Alternatively, the impaired collateral is only substituted by the sponsor. In this situation, where $\mathrm{F}^{f}$ is the optimal state but $\mathrm{F}^{s}$ is being used instead, the transaction incurs losses and vice versa. On the other hand, where the correct transaction format is used, there is neither a gain nor a loss. Hence the value of the transaction format choice (compare with (5.4) where F is used) is

$$
\mathrm{F}_{t}=\max \left\{\left|\mathrm{F}_{t}^{f}-\mathrm{F}_{t}^{s}\right|, 0\right\}
$$

Furthermore, we denote the value of the adverse selection problem by $V^{a}$. In this case, the transaction is an assignment and the sponsor is the servicer. Here, the sponsor will typically substitute impaired collateral, and hence is incentivized not to prefer the best collateral as a replacement. In this regard, we denote impaired collateral, value of replacement collateral and the value of average-quality collateral available for replacement by $C^{0}, C^{i} \ldots C^{n}$ and $C^{a}$, respectively. We assume that collateral consists of units of the same or similar sizes where $\mathbf{P}^{i}$ is the probability of there being impaired collateral and $\mathbf{P}^{a}$ the probability that the servicer/sponsor will offer medium-or low-quality collateral as replacement for the impaired collateral. In this situation, it follows that $V^{a}$ in (5.4) may be represented by

$$
V^{a}=\int_{0}^{t}\left\{\sum C^{a} * \mathbf{P}^{i}\left(1-\mathbf{P}^{a}\right)\right\}
$$

Another remark about profitability is that during the SMC, profits at the 8533 U.S. banks insured by the FDIC fell from $\$ 35.2$ billion to $\$ 646$ million (effectively by $89 \%$ ) during Quarter 4 of 2007 when compared with the previous year. This was largely due to escalating loan losses and provisions for loan losses. This decline in profits contributed to the worst bank and thrift quarterly performance since 1990. In 2007, these banks earned approximately $\$ 100$ billion, which represented a decline of 31\% from the record profit of $\$ 145$ billion in 2006. Profits decreased from $\$ 35.6$ billion to $\$ 19.3$ billion during the first quarter of 2008 versus the previous year, a decline of $46 \%$ (see [46, 47] for more detail). The contribution [34] considers the following strategy to be optimal for banks to shield their profits from loan losses. The loan loss reserves, $R^{l}$, is built up in every period that $P>L$. On the other hand, when $P \leq L$ the bank is allowed to draw on $R^{l}$ from the current period. When $R^{l}$ or other capital becomes inadequate, at some point, the bank will face insolvency.

Bank valuations as realized by (3.16) in Subsection 3.4.1 have declined dramatically during the SMC as a direct result of sharp decreases in profitability and bank capital. 


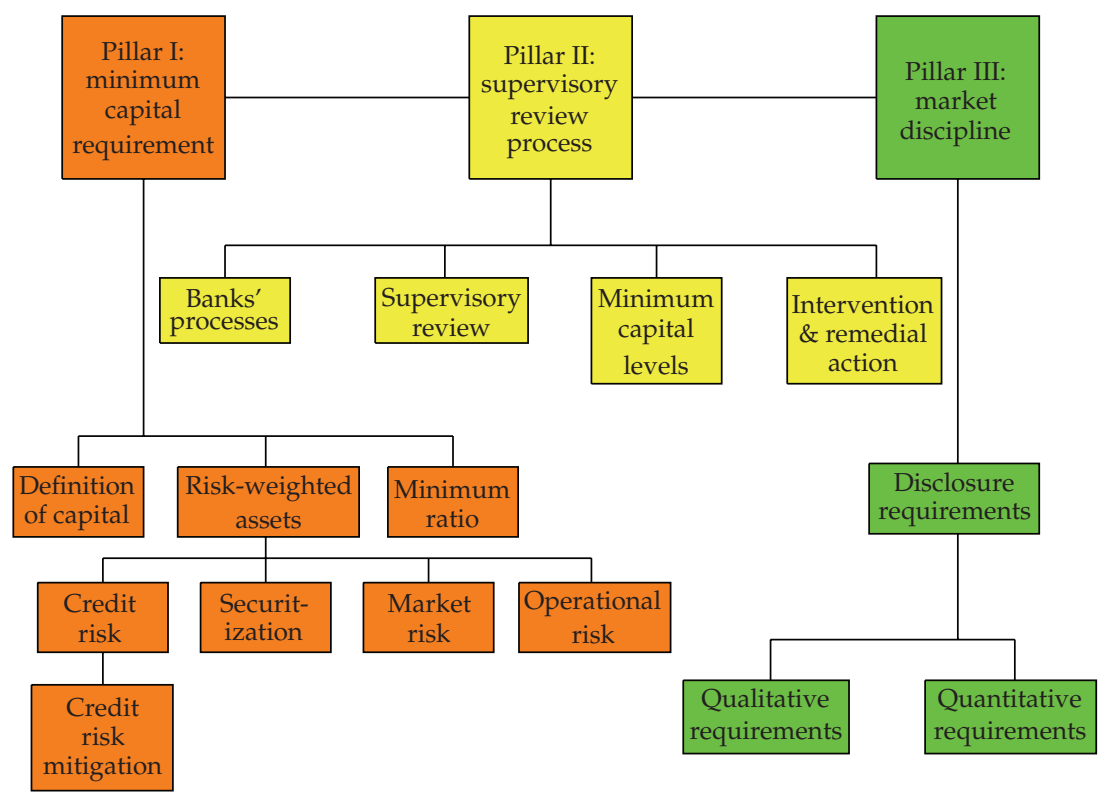

Figure 7: Diagrammatic overview of the Basel II Capital Accord.

\subsection{Bank valuation and Basel II}

In this subsection, we analyze the connections between our banking model and the Basel II Capital Accord (see Subsection B on pages 43 to 44 for a diagrammatic overview of Basel II; also $[1,2])$. These relationships are forged via the

(i) description of total bank capital given by (3.1) in Subsection 3.1.2;

(ii) description of the bank capital constraint given by (3.4) and (3.6) in Subsection 3.1.3;

(iii) procyclicality described in Subsections 3.1.3 and 4.1.

\subsubsection{Diagrammatic overview of the Basel II Capital Accord}

Next, we provide a diagrammatic overview of the Basel II Capital Accord as shown in Figure 7.

\subsubsection{Bank regulatory capital}

Despite the analysis in Subsubsections 3.1.1 and 3.1.2 of Section 3, bank capital is notoriously difficult to define, monitor and measure. For instance, the measurement of equity depends on how all of a bank's financial instruments and other assets are valued. The description of the shareholder equity component of bank capital, $E$, given by (3.1), is largely motivated by the following two observations. Firstly, it is meant to reflect the nature of the book value of equity. Our intention is also to recognize that the book and market value of equity is highly correlated.

Under Basel II, bank capital requirements have replaced reserve requirements (see Subsection 2.1) as the main constraint on the behavior of banks (see, for instance, [62]). 
A first motivation for this is that bank capital has a major role to play in overcoming the moral hazard problem arising from asymmetric information between banks, creditors and debtors. Also, bank regulators require capital to be held to protect themselves against the costs of financial distress, agency problems and the reduction of market discipline caused by the safety net. Subsection 3.1.3 suggests that a close relationship exists between bank capital holding and macroeconomic activity in the loan market (see equation (3.6) describing the bank capital constraint).

\subsubsection{Procyclicality of Basel II regulation}

Our paper has discussed the procylicality induced by the Basel II Capital Accord's approach to credit risk in Subsections 3.1.3 and 4.1. In this regard, the Standardized approach to credit risk differentiates assets not only according to the borrower but according to riskiness proxied by credit rating agencies' assessment of the borrower. This approach represents an improvement in the sense that corporations are rated. However, it is deficient with respect to the viewpoint that ratings properly reflect risk and the inducing of procyclical capital charges which will lead to overlending during booms and underlending during recessions. Also, the capital formula for the IRB approach to credit risk is problematic. In short, the IRB capital formula is deduced by considering the large-portfolio asymptotic dynamics of a Merton model with a single common risk-factor. Many empirical studies have confirmed that this formula gives rise to procyclicality.

In addition, Basel II dictates that a macroeconomic shock will affect the loan riskweights in the CAR. In general, a negative (positive) shock results in the tightening (loosening) of the capital constraint (see equation (3.6) describing the bank capital constraint). As a consequence, in terms of a possible binding capital constraint, banks are free to increase (decrease) the loan supply when macroeconomic conditions $\mathrm{M}_{t}$ improve (deteriorate). On the other hand, if the risk-weights are constant, a shock does not affect the loan supply but rather results in a change in the loan rate when the capital constraint binds. It is not always true that Basel II risk-sensitive weights lead to an increase (decrease) in bank capital when macroeconomic activity in the loan market increases (decreases). A simple explanation for this is that macroeconomic conditions do not necessarily only affect loan demand but also influences the total capital constraint (see equation (3.6) describing the bank capital constraint). Furthermore, banks do not necessarily need to raise new capital to expand their loan supply, since a positive macroeconomic shock may result in a decrease in the RWAs with a commensurate increase in CARs (compare the minimum capital constraint as expressed in (3.4) and (3.6)). Similarly, banks are not compelled to decrease their capital when the loan demand decreases since the capital constraint usually tightens in response to a negative macroeconomic shock. A further complication is that an improvement in the latter conditions may result in an increase in the loan demand and, as a consequence, an increase in the probability that the capital constraint may be binding (see equations (2.11) and (3.6) for the loan demand and bank capital constraint, resp.). Banks may react to this situation by increasing capital to maximize profits (compare the definition of the return on equity (ROE) measure of profitability). Our main conclusion is that bank capital is procyclical because it is dependent on fluctuations in loan demand which, in turn, is reliant on macroeconomic activity (see equation (3.6) describing the bank capital constraint).

\section{Concluding remarks and future research}

In this paper, we have forged connections between discrete-time stochastic banking models and macroeconomic activity as well as the SMC and Basel II Capital Accord. Furthermore, 
we solved an optimal bank valuation problem that, amongst other things, maximized profit under several realistic banking constraints. A comprehensive illustration of some of the concepts discussed in the main body of the paper was provided. The discussion of procyclicality confirms that loan loss provisions increase as world economies move further into recession. Also, we demonstrate that banks increase loan loss provisions as loan problems become more apparent. In short, this contribution represents a starting point for studying modeling issues related to the SMC and, to a lesser extent, Basel II. We envisage that our study on the modeling of the SMC will be extended in several directions in the near future.

Future modeling research should consider the bank's lending responses to business cycles as it pertains to the nexus between the proximity to its capital constraints and its forthrightness in recognizing loan losses. This relationship may not be constant over time. Further research should also establish a solid basis for comparison of extant valuation practice and demonstrate the superiority of our model to another model. In particular, we need to learn more about the inadequacies of current practice as a basis for substantiating the need for our modeling paradigm. Moreover, future reserach should provide empirical support to demonstrate the superiority of our model over other models or the accuracy of its performance relative to any market benchmark. Hence, even if one could utilize the model in some valuation project to estimate the value of the bank's common shareholder's equity, we have no idea of how close we might be to the truth with respect to market values. Since fair market values are of great interest to valuators, a test of reasonable congruence with such values would seem to be prerequisite to the use of the valuation model for purposes of business valuation. Although large sample empirical data would be preferred, smaller sample analysis using recent actual acquisitions might also be helpful. All these facts have to be incorporated in future modeling programmes.

Another research topic will involve complex models of bank items driven by Lévy processes (see, for instance, Protter in [63, Chapter I, Section 4]). Such processes have an advantage over the more traditional modelling tools such as Brownian motion because the behavior of bank loans, wealth, capital and CARs are characterized by jumps. As a result of this, recent research has strived to replace the existing Brownian motion-based bank models (see, for instance, $[3,18,20,23,64]$ ) by systems driven by more general processes. Also, a study of the optimal capital structure should ideally involve the consideration of taxes and costs of financial distress, transformation costs, asymmetric bank information and the regulatory safety net. Another research area that is of ongoing interest is the (credit, market, operational, liquidity, securitization) risk minimization of bank operations within a regulatory framework (see, for instance, $[38,43]$ ). Another risk that becomes important is interest rate risk at the point of loan issuing. For instance, an alternative optimization problem would be to maximize the risk-free rate of interest in order to provide a shareholder with an incentive to invest money. An example of a over-simplified model that has become more important during the current SMC and global credit crunch is the Diamond-Dybvig model (see, for instance, $[44,45]$ ). Their contributions proposes a much simpler model than ours but yet explains key aspects of what bank liquidity means in reality ceteris parabis. In future, it will be worthwhile to explore connections with the work of Diamond and Dybvig on liquidity.

\section{Appendices}

In this section, we firstly discuss the formal derivation of the first order conditions (3.23) to (3.26). Next, we provide diagrammatic overviews of the subprime mortgage crisis and Basel 


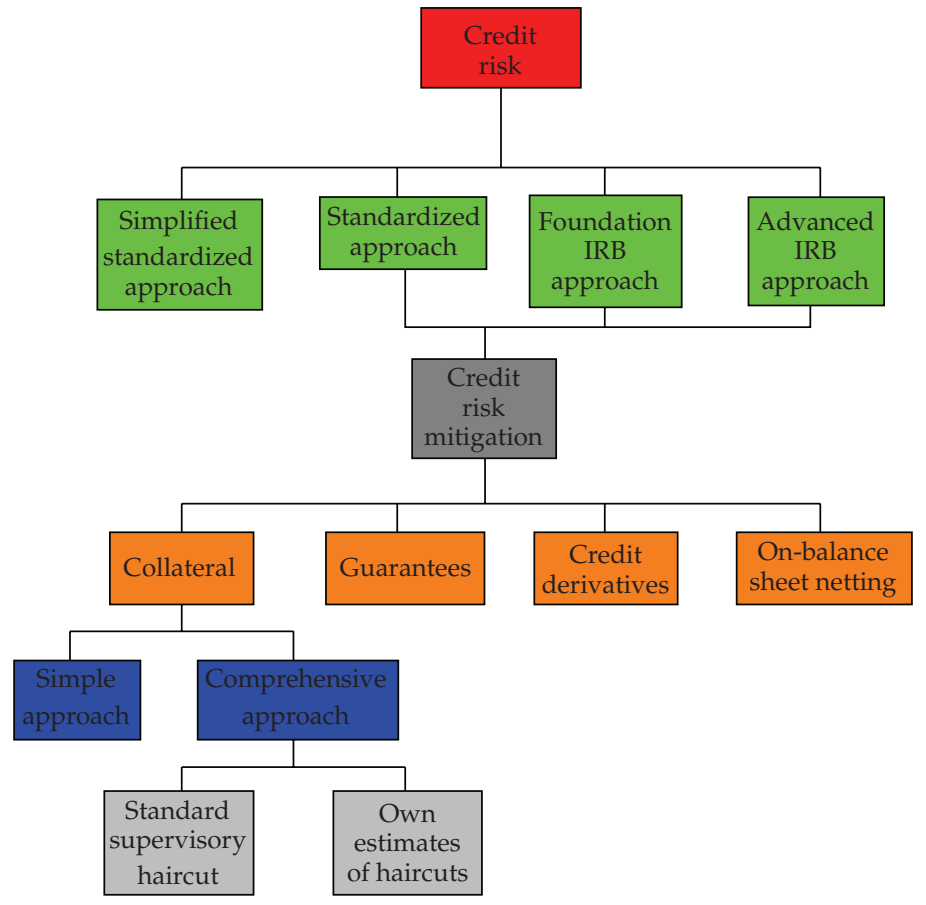

Figure 8: Diagrammatic overview of Basel II Credit Risk.

II Credit Risk (see Figure 8) as well as borrowing under securitization strategies (see Figure 9) and the financial leverage profit engine (see Figure 10).

\section{A. Derivation of first order conditions (3.23) to (3.26)}

To derive (3.23) to (3.26), we rewrite (3.17) to become

$$
\begin{gathered}
V\left(K_{t}, x_{t}\right)=\max _{r_{t}^{\mathrm{A}}, D_{t}, \Pi_{t}}\left\{\Pi_{t}+l_{t}\left[K_{t}-\rho\left(\omega\left(\mathrm{M}_{t}\right) \Lambda_{t}+\omega^{I} I_{t}+\omega^{S} S_{t}+12.5(m \mathrm{VaR}+0)\right)\right]\right. \\
\left.-c_{t}^{\mathrm{dw}}\left[K_{t+1}\right]+\mathbf{E}_{t}\left[\delta_{t, 1} V\left(K_{t+1}, x_{t+1}\right)\right]\right\}
\end{gathered}
$$

but

$$
\Pi_{t}=n_{t}\left(d_{t}+E_{t}\right)+\left(1+r_{t}^{O}\right) O_{t}-K_{t+1}+\Delta F_{t} .
$$

By substituting (2.11) and (A.2), (A.1) becomes

$$
\begin{aligned}
V\left(K_{t}, x_{t}\right)=\max _{r_{t}^{\Lambda}, D_{t}, \Pi_{t}}\{ & \left(n_{t}\left(d_{t}+E_{t}\right)+\left(1+r_{t}^{O}\right) O_{t}-K_{t+1}+\Delta F_{t}\right) \\
& +l_{t}\left[K_{t}-\rho\left[\omega\left(\mathrm{M}_{t}\right)\left(l_{o}-l_{1} r_{t}^{\Lambda}+l_{2} \mathrm{M}_{t}+\sigma_{t}^{\Lambda}\right)+\omega^{I} I_{t}+\omega^{S} S_{t}\right.\right. \\
& +12.5(m \mathrm{VaR}+0)]]-c_{t}^{\mathrm{dw}}\left[K_{t+1}\right] \\
& \left.+\mathrm{E}_{t}\left[\delta_{t, 1} V\left(K_{t+1}, x_{t+1}\right)\right]\right\} .
\end{aligned}
$$




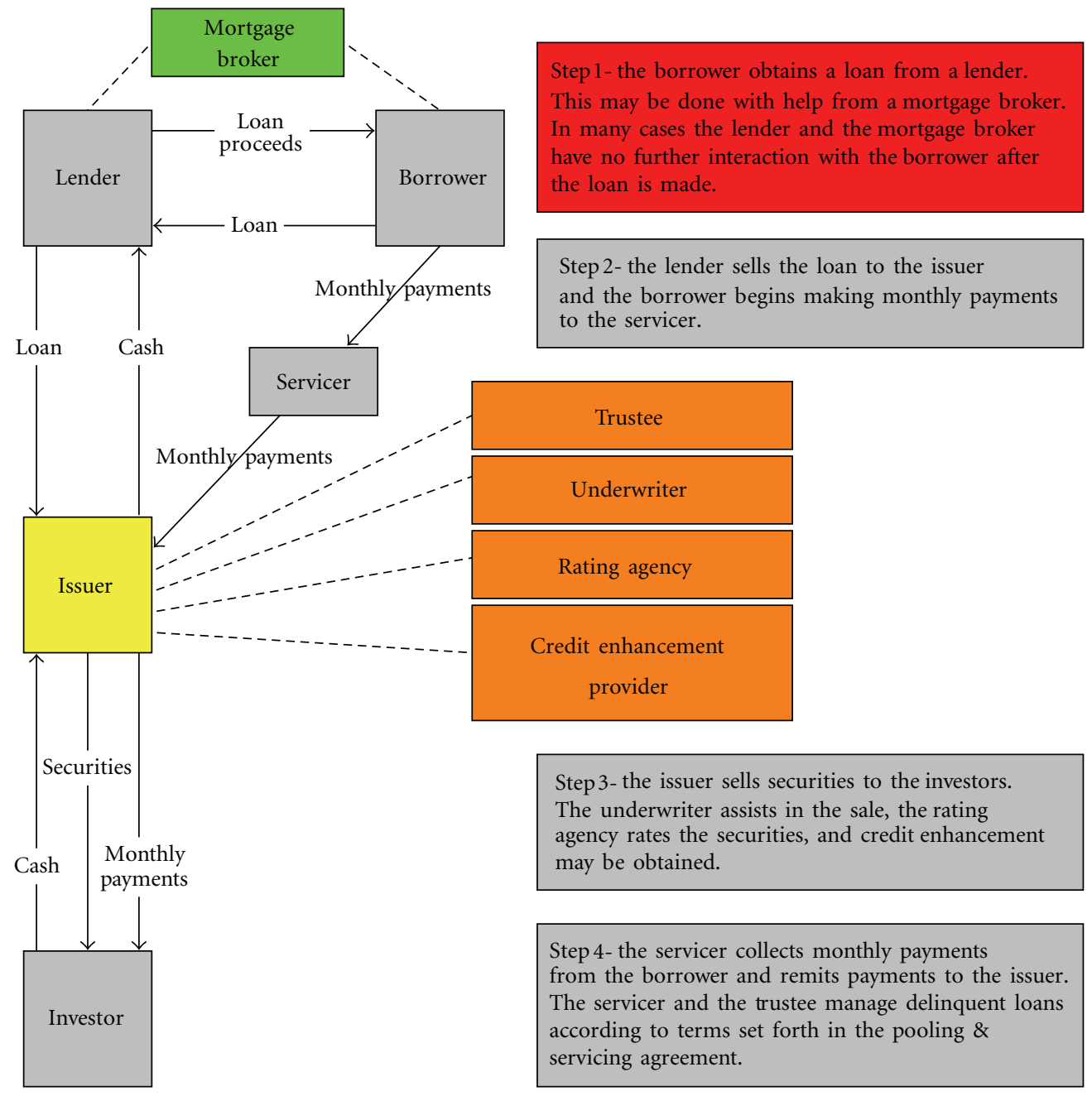

Figure 9: Diagrammatic overview of borrowing under securitization strategies (compare [51]).

Finding the partial derivative of the bank value in (A.3), with respect to the capital constraint, $K_{t+1}$, we have

$$
\frac{\partial V}{\partial K_{t+1}}=-1-c_{t}^{\mathrm{dw}}+E_{t}\left[\int_{\underline{\Lambda}}^{\bar{\Lambda}} \delta_{t, 1} \frac{\partial V}{\partial K_{t+1}} d F\left(\sigma_{t+1}^{\Lambda}\right)\right]
$$

\section{A.1. First order condition (3.23)}

Choosing the loan rate, $r_{t}^{\Lambda}$, from (A.3) and using (A.4) above, the first order condition (3.23) for Problem 4 is

$$
\frac{\partial \Pi_{t}}{\partial r_{t}^{\Lambda}}\left[1+c_{t}^{\mathrm{dw}}-\mathbf{E}_{t}\left\{\int_{\underline{\Lambda}}^{\bar{\Lambda}} \delta_{t, 1} \frac{\partial V}{\partial K_{t+1}} d F\left(\sigma_{t+1}^{\Lambda}\right)\right\}\right]+l_{t} \rho l_{1} \omega\left(\mathrm{M}_{t}\right)=0
$$




\section{A.2. First order condition (3.24)}

Choosing the deposits, $D_{t}$, from (A.3) and using (A.4) above, the first order condition (3.24) for Problem 4 is

$$
\frac{\partial \Pi_{t}}{\partial r_{t}^{\Lambda}}\left[1+c_{t}^{\mathrm{dw}}-\mathbf{E}_{t}\left\{\int_{\underline{\Lambda}}^{\bar{\Lambda}} \delta_{t, 1} \frac{\partial V}{\partial K_{t+1}} d F\left(\sigma_{t+1}^{\Lambda}\right)\right\}\right]=0
$$

\section{A.3. First order condition (3.25)}

We now find the partial derivative of the bank value in (A.3) with respect to the Lagrangian multiplier, $l_{t}$.

$$
\frac{\partial V}{\partial l_{t}}=K_{t}-\rho\left[\omega\left(\mathrm{M}_{t}\right) \Lambda_{t}+\omega^{I} I_{t}+\omega^{S} S_{t}+12.5(m \mathrm{VaR}+0)\right]
$$

Therefore the first order condition (3.25) for Problem 4 is

$$
\rho\left[\omega\left(\mathrm{M}_{t}\right) \Lambda_{t}+\omega^{I} I_{t}+\omega^{S} S_{t}+12.5(m \mathrm{VaR}+0)\right] \leq K_{t}
$$

\section{A.4. First order condition (3.26)}

Choosing the regulatory capital, $\Pi_{t}$, from equation (A.3) and using equation (A.4) above, the first order condition (3.26) for Problem 4 is

$$
-1-c_{t}^{\mathrm{dw}}+\mathbf{E}_{t}\left\{\int_{\underline{\Lambda}}^{\bar{\Lambda}} \delta_{t, 1} \frac{\partial V}{\partial K_{t+1}} d F\left(\sigma_{t+1}^{\Lambda}\right)\right\}+1=0
$$

which is the same as

$$
-c_{t}^{\mathrm{dw}}+\mathbf{E}_{t}\left\{\int_{\underline{\Lambda}}^{\bar{\Lambda}} \delta_{t, 1} \frac{\partial V}{\partial K_{t+1}} d F\left(\sigma_{t+1}^{\Lambda}\right)\right\}=0,
$$

\section{B. Diagrammatic overview of Basel II Credit Risk}

In this appendix, we provide a diagrammatic overview of Basel II Credit Risk as shown in Figure 8 .

\section{Securitization}

In this section, we provide more information about securitization with regard to borrowing under securitization strategies (see Figure 9) and the financial leverage profit engine (see Figure 10) as presented on the website [51]. 


\section{C.1. Borrowing under securitization strategies}

A diagrammatic overview of borrowing under securitization strategies may be represented as shown in Figure 9.

A simpler procedure for borrowing under an MBS strategy may be summarized as follows. The bank lends money to the borrower (homeowner). The bank creates an asset pool from a group of equivalent assets and sells CMO certificates to investors. The mortgage holders pay periodic payments to the bank. The bank collects mortgage payments, extracts servicing fees, pays guarantee fees to the trustees and passes the rest of the payment on to the investors. In the case where the mortgage holder defaults the trustee pays the remaining mortgage balance to the investors. Next, a diagrammatic overview of the financial leverage profit engine that is closely related to borrowing under securitization strategies will be given.

\section{C.2. The financial leverage profit engine}

Further insight may be gained about securitization by considering the following illustration (compare with Figure 10). Let us assume that an investment bank borrows money from an investor or money market fund and agrees to pay, for instance, $4 \%$ interest rate. The MBS portfolio is collateral, which the investors can seize in the event of a default on interest payments. The investment bank uses the funds to expand its MBS portfolio, which is paying, for instance, $7 \%$ interest rate. The 3\% rate difference between the amounts is called the spread. In our case, for every R 100.00 invested in this manner, the investment bank makes R 3.00 profit margin. This provides an incentive to borrow and invest as much as possible, known as leveraging. This was considered safe during the early 2007 housing boom, as MBS portfolios typically received high credit ratings and defaults were minimal. Since investment banks do not have the same capital reserve requirements as depository banks, many borrowed and lent amounts exceeding 30 times their net worth. By contrast, depository banks rarely lend more than 15 times their net worth. Freddie Mac was leveraged nearly 70 times its net worth. With increasing delinquencies and foreclosures during 2007-2008, the value of the MBS portfolios declined. Investors became concerned and in some cases demanded their money back, resulting in margin calls (need to sell/liquidate the MBS portfolios) to pay them. At such a high leverage amount, many investment banks and mortgage companies suffered huge losses, bankruptcy, or merged with other institutions. Because MBS securities became "toxic" due to uncertainty in the housing market, they became illiquid and their values dropped. The market value is penalized by the inability to sell the MBS; it may be less than the value the actual cash inflow would merit. The ability of financial institutions to obtain funds in this manner via MBS has been dramatically curtailed. Spreads have narrowed, as investors are demanding higher returns to lend money to highly leveraged institutions.

\section{Key definitions}

In this subsection, we present the definitions of a few key concepts as provided by, for instance, [51].

Credit crunch is a term used to describe a sudden reduction in the general availability of loans (or credit) or sudden increase in the cost of obtaining loans from banks (by raising interest rates).

Special purpose vehicle (SPV): A SPV is a body corporate (usually a limited company of some type or, sometimes, a limited partnership) created to fulfill narrow, specific or 


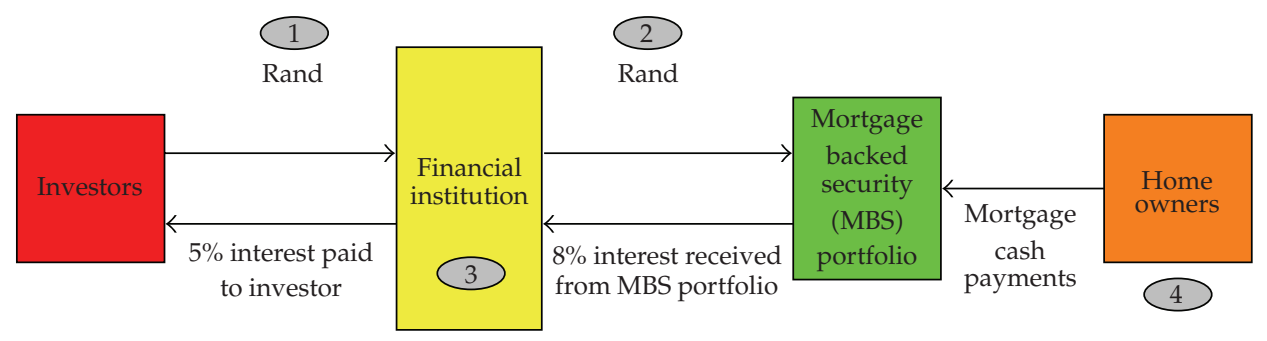

Figure 10: Diagrammatic Overview of the Financial Leverage Profit Engine (compare [51]).

temporary objectives, primarily to isolate financial risk, usually bankruptcy but sometimes a specific taxation or regulatory risk. A SPV may be owned by one or more other entities and certain jurisdictions may require ownership by certain parties in specific percentages. Often it is important that the SPV not be owned by the entity on whose behalf the SPV is being set up by the sponsor. For example, in the context of a loan securitization, if the SPV securitization vehicle were owned or controlled by the bank whose loans were to be secured, the SPV would be consolidated with the rest of the bank's group for regulatory, accounting, and bankruptcy purposes, which would defeat the point of the securitization. Therefore many SPVs are set up as "orphan" companies with their shares settled on charitable trust and with professional directors provided by an administration company to ensure there is no connection with the sponsor.

Mortgage-backed security: a mortgage-backed security (MBS) is an asset-backed security whose cash flows are backed by the principal and interest payments of a set of mortgage loans. Payments are typically made monthly over the lifetime of the underlying loans. Residential mortgages in the United States have the option to pay more than the required monthly payment (curtailment) or to pay off the loan in its entirety (prepayment). Because curtailment and prepayment affect the remaining loan principal, the monthly cash flow of an MBS is not known in advance, and therefore presents an additional risk to MBS investors. Commercial mortgage-backed securities (CMBS) are secured by commercial and multifamily properties (such as apartment buildings, retail or office properties, hotels, schools, industrial properties and other commercial sites). The properties of these loans vary, with longerterm loans ( 5 years or longer) often being at fixed interest rates and having restrictions on prepayment, while shorter-term loans (1-3 years) are usually at variable rates and freely prepayable.

Subprime lending is the practice of making loans to borrowers who do not qualify for market interest rates owing to various risk factors, such as income level, size of the down payment made, credit history and employment status.

Project finance (PF) is a method of funding in which the lender looks primarily to the revenues generated by a single project, both as the source of repayment and as security for the exposure.

Object finance (OF) refers to a method of funding the acquisition of physical assets (e.g., ships, aircraft, satellites, railcars, and fleets) where the repayment of the exposure is dependent on the cash flow generated by the specific assets that have been financed and pledged or assigned to a lender. A primary source of these cash flows might be rental or lease contracts with one or several parties.

Commodities finance ( $\mathrm{CF}$ ) refers to structured short-term lending to finance reserves, inventories, or receivable of exchange-traded commodities (e.g., crude oil, metals, or crops), 
where the exposure will be repaid from the proceeds of the sale of the commodity and the borrower has no independent capacity to repay the exposure. This is the case when the borrower has no other activities and no other material assets on its balance sheet.

Income producing real estate (IPRE) refers to a method of providing funding to real estate (such as, office buildings to let, retail space, multifamily residential buildings, industrial or warehouse space and hotels) where the prospects for repayment and recovery on the exposure depend primarily on the cash flow generated by the asset. The primary source of these cash flows would generally be lease or rental payments or the sale of the asset.

High volatility commercial real estate (HVCRE) lending is the financing of commercial real estate that exhibits higher loss rate volatility (e.g., higher asset correlation).

Specialized lending high volatility commercial real estate (SLHVCRE) includes commercial real estate exposures secured by properties of types that are categorized by the national supervisor as sharing higher volatilities in portfolio defaults rates; loans financing any of the land acquisition, development and construction (ADC) phases for properties of those types in such jurisdiction; loans financing ADC of any other properties where the source of repayment at origination of the exposure is either the future uncertain sale of the property or cash flows whose source of repayment is substantially uncertain (e.g., the property has not yet been leased to the occupancy rate prevailing in that geographic markets for that type of commercial real estate), unless the borrower has substantial equity at risk.

The asset class, bank exposure (BE), covers exposures to banks and securities firms that are subject to supervisory and regulatory arrangements comparable to those under Basel II. Bank exposure also includes claims on domestic public sector entities (PSEs) that are treated like claims on banks under the Standardized approach, and multilateral development banks (MDBs) that do not meet the criteria for $0 \%$ risk weight under the Standardized approach.

Sovereign exposure (SE), covers all exposures to counterparties treated as sovereign under the Standardized approach. This includes sovereigns (and their central banks), certain PSEs identified as sovereigns in the Standardized approach, MDBs that meet the criteria for $0 \%$ risk weight under the Standardized approach.

Retail residential mortgage (RRM)loans (including first and subsequent liens ( In law, a lien is a form of security interest granted over an item of property to secure the payment of a debt or performance of some other obligation. The owner of the property, who grants the lien, is referred to as the lienor and the person who has the benefit of the lien is referred to as the lienee.), term loans and revolving (HELOC) home equity lines of credit) are eligible for retail treatment regardless of exposure size so long as the credit is extended to an individual that is an owner-occupier of the property.

\section{References}

[1] Basel Committee on Banking Supervision, "The New Basel Capital Accord," Bank for International Settlements, May 2001, http:/ / www.bis.org/publ/bcbsca.htm.

[2] Basel Committee on Banking Supervision, "International Convergence of Capital Measurement and Capital Standards: A Revised Framework," Bank for International Settlements, June 2006, http://www.bis.org/publ/bcbs107.pdf.

[3] J. Mukuddem-Petersen, M. A. Petersen, I. M. Schoeman, and B. A. Tau, "Maximizing banking profit on a random time interval," Journal of Applied Mathematics, vol. 2007, Article ID 29343, 22 pages, 2007.

[4] J. Mukuddem-Petersen, M. A. Petersen, I. M. Schoeman, and B. A. Tau, "Dynamic modelling of bank profits," Applied Financial Economics Letters, vol. 4, no. 3, pp. 157-161, 2008.

[5] J. R. M. Hand and B. Lev, Intangible Assets: Values, Measures and Risks, Oxford University Press, Oxford, UK, 2003.

[6] G. J. Whitwell, B. A. Lukas, and P. Hill, "Stock analysts' assessments of the shareholder value of intangible assets," Journal of Business Research, vol. 60, no. 1, pp. 84-90, 2006. 
[7] R. Chami and T. F. Cosimano, "Monetary policy with a touch of Basel," Working Paper no. WP/01/151, International Monetary Fund, October 2001.

[8] D. Ruthenberg and Y. Landskroner, "Loan pricing under Basel II in an imperfectly competitive banking market," Journal of Banking E Finance, vol. 32, no. 12, pp. 2725-2733, 2008.

[9] R. Repullo and J. Suarez, "Loan pricing under Basel capital requirements," Journal of Financial Intermediation, vol. 13, no. 4, pp. 496-521, 2004.

[10] S. Djankov, J. Jindra, and L. F. Klapper, "Corporate valuation and the resolution of bank insolvency in East Asia," Journal of Banking and Finance, vol. 29, no. 8-9, pp. 2095-2118, 2005.

[11] G. S. Fissel, L. Goldberg, and G. A. Hanweck, "Bank portfolio exposure to emerging markets and its effects on bank market value," Journal of Banking E Finance, vol. 30, no. 4, pp. 1103-1126, 2006.

[12] T. J. Coyne, "Commercial bank profitability by function," Financial Management, vol. 2, no. 1, pp. 6473, 1973.

[13] A. Demirgüc-Kunt and H. Huizinga, "Determinants of commercial bank interest margins and profitability: some international evidence," Working Paper no. WPS 1900, The World Bank Policy Research, November 1999.

[14] G. M. Halkos and M. N. Georgiou, "Bank sales, spread and profitability: an empirical analysis," Applied Financial Economic Letters, vol. 1, no. 5, pp. 293-296, 2005.

[15] F. Modigliani and M. Miller, "The cost of capital, corporation finance and the theory of investment," American Economic Review, vol. 48, no. 3, pp. 261-297, 1958.

[16] A. N. Berger, R. J. Herring, and G. Szegö, "The role of capital in financial institutions," Journal of Banking and Finance, vol. 19, no. 3-4, pp. 393-430, 1995.

[17] D. W. Diamond and R. G. Rajan, "A theory of bank capital," The Journal of Finance, vol. 55, no. 6, pp. 2431-2465, 2000.

[18] H. Leland, "Risky debt, bond covenants and optimal capital structure," The Journal of Finance, vol. 49, no. 4, pp. 1213-1252, 1994.

[19] T. Dangl and J. Zechner, "Credit risk and dynamic capital structure choice," Journal of Financial Intermediation, vol. 13, no. 2, pp. 183-204, 2004.

[20] J.-P. Decamps, J.-C. Rochet, and B. Roger, "The three pillars of Basel II: optimizing the mix," Journal of Financial Intermediation, vol. 13, no. 2, pp. 132-155, 2004.

[21] J. Mukuddem-Petersen and M. A. Petersen, "Stochastic behaviour of risk-weighted bank assets under the Basel II capital accord," Applied Financial Economics Letters, vol. 1, no. 3, pp. 133-138, 2005.

[22] R. Repullo, "Capital requirements, market power, and risk-taking in banking," Journal of Financial Intermediation, vol. 13, no. 2, pp. 156-182, 2004.

[23] J. C. Rochet, "Rebalancing the three pillars of Basel II," Economic Policy Review, vol. 10, no. 2, pp. 7-25, 2004.

[24] D. Hancock, A. J. Laing, and J. A. Wilcox, "Bank capital shocks: dynamic effects and securities, loans and capital," Journal of Banking \& Finance, vol. 19, no. 3-4, pp. 132-155, 1995.

[25] A. V. Thakor, "Capital requirements, monetary policy, and aggregate bank lending: theory and empirical evidence," The Journal of Finance, vol. 51, no. 1, pp. 279-324, 1996.

[26] S. Altug and P. Labadie, Dynamic Choice and Asset Markets, San Diego, Calif, USA, Academic Press, 1994.

[27] R. Bliss and G. Kaufman, "Bank procyclicality, credit crunches and asymmetric monetary policy effects: a unifying model," Working Paper no. WP-02-18, Federal Reserve Bank of Chicago, November 2002.

[28] E. Catarineu-Rabell, P. Jackson, and D. P. Tsomocos, "Procyclicality and the new Basel Accord-Bank's choice of loan rating system," Working Paper no. 181, Bank of England, August 2003.

[29] N.-K. Chen, "Bank net worth, asset prices and economic activity," Journal of Monetary Economics, vol. 48 , no. 2, pp. 415-436, 2001.

[30] D. Tsomocos, "Equilibrium analysis, banking, contagion and financial fragility," Working Paper no. 175, Bank of England, 2003.

[31] S. van den Henvel, "Does bank capital matter for monetary transmission?" Economic Policy Review, vol. 8, no. 1, pp. 259-265, 2002.

[32] D. Hackbarth, J. Miao, and E. Morellec, "Capital structure, credit risk, and macroeconomic conditions," Journal of Financial Economics, vol. 82, no. 3, pp. 519-550, 2006.

[33] A. Anandarajan, I. Hasan, and A. Lozano-Vivas, "Loan loss provision decisions: an empirical analysis of the Spanish depository institutions," Journal of International Accounting, Auditing and Taxation, vol. 14 , no. 1, pp. 55-77, 2005. 
[34] J. A. Bikker and P. A. J. Metzemakers, "Bank provisioning behaviour and procyclicality," Journal of International Financial Markets, Institutions and Money, vol. 15, no. 2, pp. 141-157, 2005.

[35] C. Borio, C. Furfine, and P. Lowe, "Procyclicality of the financial system and financial stability: issues and policy options," Working Paper, Bank for International Settlements, April 2001, http://www.bis.org/publ/bppdf/bispap01a.pdf.

[36] M. Cavallo and G. Majnoni, "Do banks provision for bad loans in good times ? Empirical evidence and policy implications," in Ratings, Rating Agencies and the Global Financial System, R. Levich, G. Majnoni, and C. Reinhart, Eds., Kluwer Academic Publishers, Boston, Mass, USA, 2002.

[37] Y. S. Demyanyk and O. Van Hemert, "Understanding the subprime mortgage crisis," August 2008, http:/ / papers.ssrn.com/sol3/papers.cfm?abstractid=1020396.

[38] J. Mukuddem-Petersen and M. A. Petersen, "Bank management via stochastic optimal control," Automatica, vol. 42, no. 8, pp. 1395-1406, 2006.

[39] L. Pelizzon and S. Schaefer, "Pillar 1 vs Pillar 2 under risk management," in NBER Conference on Risks of Financial Institutions, M. Carey and R. Stulz, Eds., Berlin, Germany, October 2005.

[40] S. Basak and A. Shapiro, "Value-at-risk-based risk management: optimal policies and asset prices," The Review of Financial Studies, vol. 14, no. 2, pp. 371-405, 2001.

[41] D. Cuoco and H. Liu, "An analysis of VaR-based capital requirements," Journal of Financial Intermediation, vol. 15, no. 3, pp. 362-394, 2006.

[42] M. Leippold, F. Trojani, and P. Vanini, "Equilibrium impact of value-at-risk regulation," Swiss Banking Institute, University of Zurich, July 2003.

[43] J. Mukuddem-Petersen and M. A. Petersen, “Optimizing asset and capital adequacy management in banking," Journal of Optimization Theory and Applications, vol. 137, no. 1, pp. 205-230, 2008.

[44] D. W. Diamond, "Banks and liquidity creation: a simple exposition of the Diamond-Dybvig model," Economic Quarterly, vol. 93, no. 2, pp. 189-200, 2007.

[45] D. W. Diamond and P. H. Dybvig, "Bank runs, deposit insurance and liquidity," Journal of Political Economy, vol. 91, no. 3, pp. 401-419, 1983.

[46] FDIC, “Quarterly Banking Profile (Pre-Adjustment)," Fourth Quarter, vol. 29, no. 1, 2008.

[47] FDIC, “Quarterly Banking Profile," First Quarter, vol. 29, no. 2, 2008.

[48] G. J. Alexander and A. M. Baptista, "Does the Basle Capital Accord reduce bank fragility? An assessment of the value-at-risk approach," Journal of Monetary Economics, vol. 53, no. 7, pp. 1631-1660, 2006.

[49] L. Laeven and G. Majnoni, "Loan loss provisioning and economic slowdowns: too much, too late?" Journal of Financial Intermediation, vol. 12, no. 2, pp. 178-197, 2003.

[50] Organization for Economic Co-Operation and Development (OECD), "Main Economic Indicators," November 2008.

[51] Wikipedia: The Free Encyclopedia, "Subprime Mortgage Crisis," November 2008, http://en .wikipedia.org/wiki/Subprime_mortgage_crisis.

[52] “PBS. Episode 06292007," Bill Moyers Journal, June 2007, http://www.pbs.org/moyers/journal/ 06292007 / transcript5.html.

[53] J. Lahart, "Egg cracks differ in housing, finance shells," The Wall Street Journal, December 2007, http:/ / online.wsj.com/article/SB119845906460548071.html.

[54] Realtytrac Staff, “US foreclosure activity increases 75 percent in 2007," May 2008, http://www .realtytrac.com/ContentManagement/pressrelease.aspx.

[55] J. Fineman and B. Keoun, “Merrill Lynch posts fourth straight quarterly loss (Update 2)," July 2008, http://www.bloomberg.com/apps/news.

[56] Y. Onaran, "Subprime losses top \$ 379 billion on balance-sheet marks: table," May 2008, http://www.bloomberg.com/apps/news.

[57] S. Matthews and S. Lanman, “Bernanke urges 'hunkering' banks to raise capital (Update 4)," May 2008, http://www.bloomberg.com/apps/news.

[58] J. Aversa, "Rebate checks in the mail by spring," The Huffington Post, Arianna Huffington, February 2008, http://www.huffingtonpost.com/2008/02/13/rebate-checks-in-the-mail_n_86525.html.

[59] US Federal Reserve, "FRB: Press Release-FOMC statement," January 2008, http://www .federalreserve.gov/newsevents/press/monetary/20080122b.htm.

[60] "Full speed ahead," The Economist, January 2008, http:/ /www.economist.com/world/unitedstates / displaystory.cfm?story_id=10589983. 
[61] D. M. Kinchen, "REALTORS: Commercial real estate pinched by Wall Street Woes," September 2008, http:/ / www.huntingtonnews.net/columns/080919-kinchen-columnsrealtors.html.

[62] T. Bosch, J. Mukuddem-Petersen, M. A. Petersen, and I. Schoeman, “Optimal auditing in the banking industry," Optimal Control Applications \& Methods, vol. 29, no. 2, pp. 127-158, 2008.

[63] P. E. Protter, Stochastic Integration and Differential Equations, vol. 21 of Applications of Mathematics, Springer, Berlin, Germany, 2nd edition, 2004.

[64] C. H. Fouche, J. Mukuddem-Petersen, and M. A. Petersen, "Continuous-time stochastic modelling of capital adequacy ratios for banks," Applied Stochastic Models in Business and Industry, vol. 22, no. 1, pp. 41-71, 2006. 


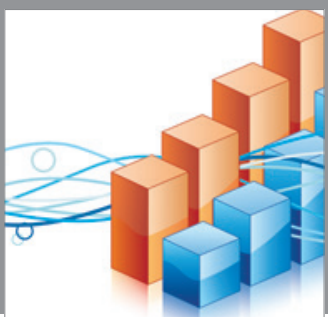

Advances in

Operations Research

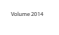

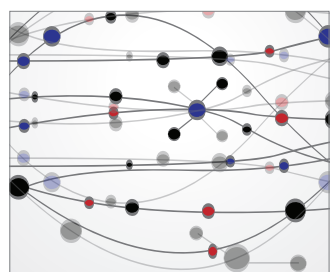

\section{The Scientific} World Journal
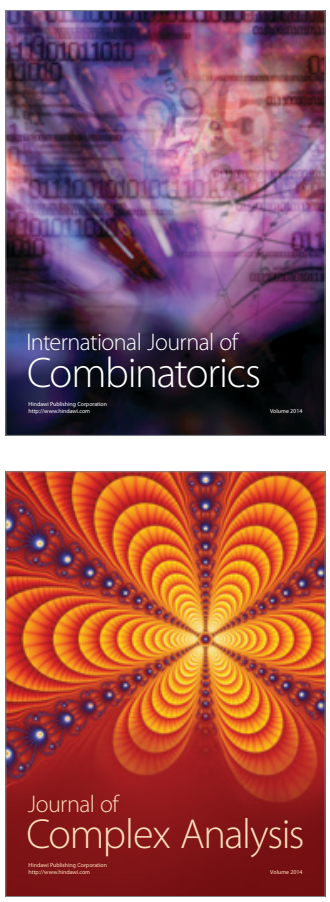

International Journal of

Mathematics and

Mathematical

Sciences
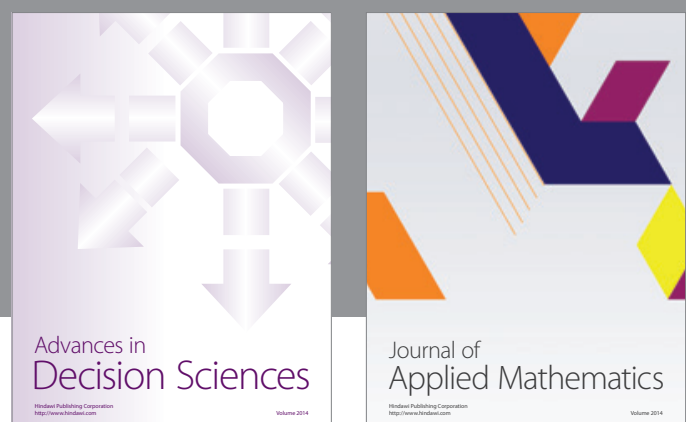

Journal of

Applied Mathematics
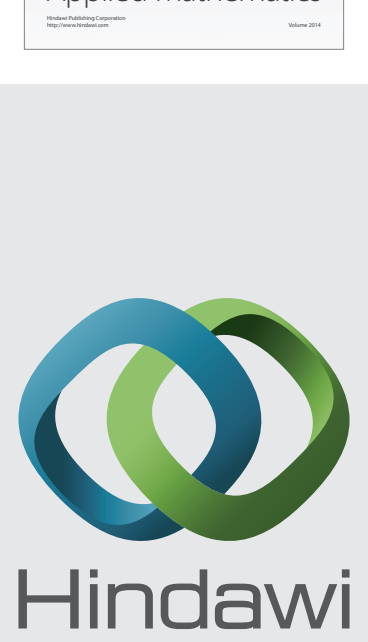

Submit your manuscripts at http://www.hindawi.com
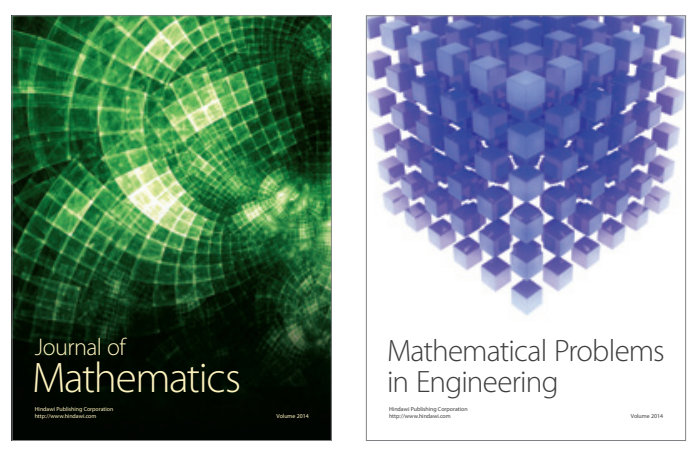

Mathematical Problems in Engineering
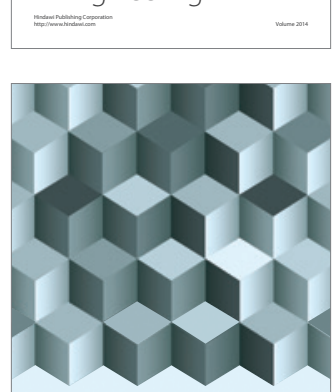

Journal of

Function Spaces
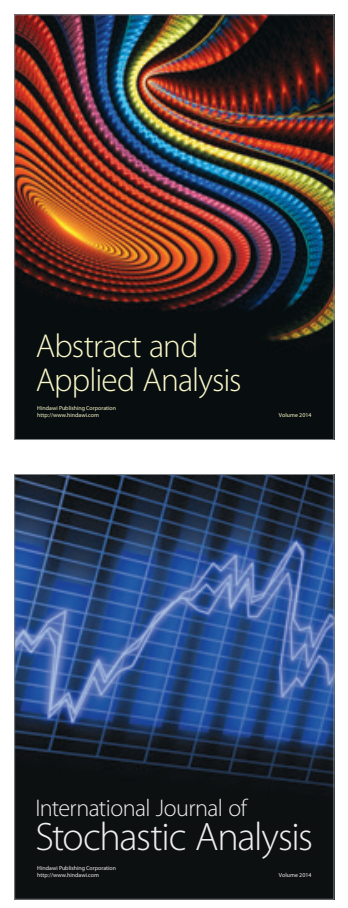

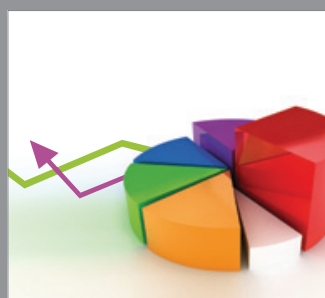

ournal of

Probability and Statistics

Promensencen
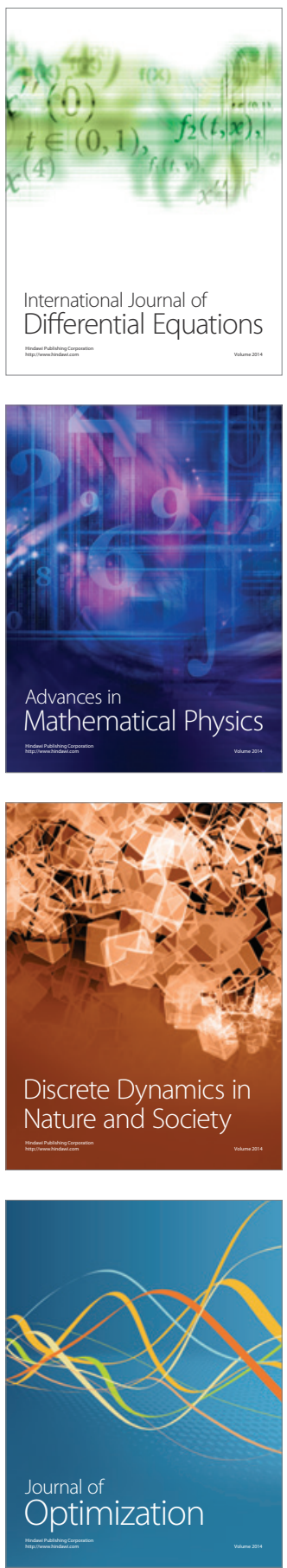